NBER WORKING PAPER SERIES

\title{
STRUCTURING AND RESTRUCTURING SOVEREIGN DEBT: THE ROLE OF SENIORITY
}

\author{
Patrick Bolton \\ Olivier Jeanne \\ Working Paper 11071 \\ http://www.nber.org/papers/w11071 \\ NATIONAL BUREAU OF ECONOMIC RESEARCH \\ 1050 Massachusetts Avenue \\ Cambridge, MA 02138 \\ January 2005
}

This paper benefitted from comments received at the 2004 Annual Meeting of the American Economic Association, the Graduate School of Business at Columbia University, the Graduate School of Business at the University of Chicago, Texas A \& M University, and the 2004 NBER Summer Institute. We especially thank Michael Adler, Marcos Chamon, Douglas Diamond, Michael Dooley, Richard Portes, Suresh Sundaresan and Jeromin Zettelmeyer for their comments. The views expressed herein are those of the author(s) and do not necessarily reflect the views of the National Bureau of Economic Research.

(C) 2005 by Patrick Bolton and Olivier Jeanne. All rights reserved. Short sections of text, not to exceed two paragraphs, may be quoted without explicit permission provided that full credit, including $\odot$ notice, is given to the source. 
Structuring and Restructuring Sovereign Debt: The Role of Seniority

Patrick Bolton and Olivier Jeanne

NBER Working Paper No. 11071

January 2005

JEL No. F3, G3

\begin{abstract}
$\underline{\text { ABSTRACT }}$
In an environment characterized by weak contractual enforcement, sovereign lenders can enhance the likelihood of repayment by making their claims more difficult to restructure. We show within a simple model how competition for repayment between lenders may result in sovereign debt that is excessively difficult to restructure in equilibrium. Alleviating this inefficiency requires a sovereign debt restructuring mechanism that fulfills some of the functions of corporate bankruptcy regimes, in particular the enforcement of seniority and subordination clauses in debt contracts.

\author{
Patrick Bolton \\ Bendheim Center for Finance \\ 26 Prospect Avenue \\ Princeton, NJ 08540-5296 \\ and NBER \\ pbolton@princeton.edu \\ Olivier Jeanne \\ IMF \\ $70019^{\text {th }}$ Street NW \\ Washington, DC 20431 \\ ojeanne@imf.org
}

Princeton University
\end{abstract}




\section{Introduction}

The composition of sovereign debt and how it affects debt restructuring negotiations in the event of financial distress, has become a central policy issue in recent years. There are two major reasons why the spotlight has been turned on this question. First, the change in the I.M.F.'s policy orientation towards sovereign debt crises, with a proposed greater weight on "private sector involvement' (Rey Report, G-10, 1996), has brought up the question of how easy it actually is to get 'the private sector involved'; that is, how easy it is to get private debt-holders to agree to a debt restructuring. Second, the experience with several recent debt restructuring episodes - some of which were followed by defaults and by private litigation to recover debt payments - have raised concerns that the uncoordinated efforts of dispersed debt-holders to renegotiate sovereign debt obligations were likely to lead to substantial delays and other inefficiencies.

These concerns have led a number of prominent commentators, a majority of G-7 countries, and the I.M.F. to advocate ex-post policy interventions to facilitate debt restructuring (see Rogoff and Zettelmeyer, 2002, for a history and overview of the different proposals). These calls for intervention have reached a culmination point when the I.M.F.'s Anne Krueger put forward the idea of a sovereign debt restructuring mechanism (SDRM) inspired by the U.S. corporate bankruptcy reorganization law under Chapter 11 of the 1978 Bankruptcy act (Krueger, 2002).

The debate triggered by these ambitious proposals for reform of the international financial architecture has left many commentators wondering why, in the first place, sovereign debt had been structured to make it difficult to renegotiate, and why the structure of sovereign debt had evolved over the past decade or so towards a greater share of sovereign bond issues and greater dispersion 
of ownership of sovereign bonds. This paper is concerned with precisely these issues. Its starting point are the questions:

1) why would a forward looking sovereign want to design a sovereign debt structure that is difficult to restructure?

2) where are the contractual failures between the borrower and lenders that justify an ex-post policy intervention to facilitate debt restructuring?

Several commentators (Dooley, 2000; Shleifer, 2003) have argued that due to the sovereign's incentive to repudiate its debts (the well known willingnessto-pay problem) it may be ex-ante efficient to structure sovereign debt to make it difficult to renegotiate ex-post. A policy intervention that aims to reduce these restructuring costs, while improving ex-post efficiency, might thus undermine ex-ante efficiency. Such a policy would have the effect of raising the cost of borrowing and would result in a reduction of lending to emerging market countries ${ }^{1}$.

Our paper considers another moral hazard problem besides the sovereign' s willingness-to-pay: the problem of debt dilution. This problem arises whenever a sovereign approaching financial distress raises new debt mainly in an effort to delay the onset of a debt crisis. This new debt dilutes existing debt by reducing the amount that can be recovered by existing debtholders in a debt renegotiation.

Our paper argues that this form of debt dilution is difficult to avoid in sovereign lending, as there is no obvious way of structuring legally binding seniority agreements nor of enforcing priority of repayment following a sovereign debt default. In contrast to corporate debt, for which courts routinely enforce creditors' subordination priorities, there is no easy way of enforcing priority

\footnotetext{
${ }^{1}$ The idea that under limited enforcement it may be desirable to create a debt structure that is difficult to renegotiate is, of course, a familiar theme in corporate finance. See, for example Hart and Moore (1995), Dewatripont and Maskin (1995), Bolton and Scharfstein (1996), Diamond and Rajan (2001) and Diamond (2004).
} 
covenants for sovereign $\mathrm{debt}^{2}$. As a result, our paper argues that when seniority is not available de jure, sovereigns attempt to achieve it de facto by making their debt issues exceedingly difficult to restructure. With each new debt issue, the sovereign is tempted to lower the cost of borrowing by commiting to high future restructuring costs of that particular issue, which encourage the sovereign to restructure first other debts with lower restructuring costs, and thus provide a form of seniority to that issue. This de facto seniority can be obtained in various ways, for example by lifting sovereign immunity, by widely dispersing the debt and insisting on a unanimity requirement for restructuring the debt, by lowering the maturity of the debt, by denominating the debt in dollars, or by inserting acceleration clauses. Thus, in the absence of legal enforcement of seniority, a form of Gresham law for sovereign debt arises - where "bad" debt structures, with inefficiently high ex-post restructuring costs, tend to crowd out "good" debt, that is easier to renegotiate in the event of financial distress.

Our paper argues that there is, therefore, a role for policy intervention in sovereign lending that would improve both ex-ante and ex-post efficiency. This policy intervention should take the form of facilitating the enforcement of priority covenants, thus allowing sovereigns to issue debt that is both easier to renegotiate and of longer maturity. Thus, our theory has some implications for the reforms of the international financial architecture that have been discussed in recent debates, and in particular the desirability of a bankruptcy regime for sovereigns (SDRM). We argue that because of the competition between borrow-

\footnotetext{
${ }^{2}$ There is a large corporate finance and legal literature, as well as a large body of case law, on debt seniority and priority covenants as instruments aimed at reducing the risk of debt dilution (see e.g. Fama and Miller, 1972, White 1980, Barclay and Smith, 1995, and Schwartz, 1989 and 1997). The insights from the corporate finance literature cannot be directly transposed to sovereign debt. The seniority of corporate debt is explicit, contractually specified and enforced by courts. It is based to a large extent on collateral. In contrast, there is very little collateral that sovereigns can offer to creditors. Of the 79 developing and emerging market countries that had at least one public sector international loan or bond outstanding on January 1, 2003, the face value of collateralized debt was only 6.2 percent of the face value of total outstanding debt (Zettelmeyer, 2003). See also Chalk (2002) and IMF (2003) for discussions of collateralized sovereign debt.
} 
ers to dilute each other, sovereign debt might be excessively hard to restructure in equilibrium even from an ex ante perspective. A bankruptcy regime for sovereigns could mitigate this inefficiency by enforcing a default seniority rule, where priority is based on a first-in-time rule whereby debts issued earlier have higher priority, and debts with longer maturity have higher priority ${ }^{3}$.

In our model, the contractual approach to sovereign debt restructuring recently endorsed by the G- $10^{4}$, which is limited to an encouragement to issuers to allow for majority-rule clauses for the restructuring of debt issues (so-called collective action clauses or CACs) does not work. First, efficiency cannot be achieved by leaving sovereign borrowers free to include or not renegotiationfriendly clauses in their debt. In equilibrium, the adoption of such clauses will be inefficiently low under laissez-faire. Second, it is also not desirable to encourage the adoption of such clauses by a system of taxes or subsidies (as advocated by Eichengreen, 1999, or Kenen, 2001), or by making their use mandatory, because this intervention would only result in higher borrowing costs without addressing in any way the debt dilution problem.

Our analysis provides support for the statutory approach to sovereign debt restructuring ${ }^{5}$. However, we emphasize that the statutory approach may easily be welfare-reducing if it is not carefully designed. In particular, a sovereign debt restructuring mechanism that simply solves coordination failures between creditors ex post reduces welfare in our model. It is crucial that the mechanism fulfill the other functions of corporate bankruptcy regimes, in particular that it establish legal seniority between creditors and that it allow for the analog of debtor-in-possession lending to the defaulted sovereign. Our emphasis on

\footnotetext{
${ }^{3}$ The first-in-time rule has been advocated for corporate debt, among others, by White (1980) and Schwartz (1989). Bolton and Skeel (2004) outline how a bankruptcy procedure for sovereigns could be designed to legally enforce such a priority rule.

${ }^{4}$ The contractual approach advocated by the official sector is outlined in G-10 (1996) and G-22 (1998).

${ }^{5}$ The statutory approach advocated by the IMF is outlined in Krueger (2002). The relationship with chapter 11 under the U.S. bankruptcy code is discussed in Bolton (2003).
} 
the need for differentiating across creditors in the debt restructuring process contrasts with the conventional wisdom that creditors should be treated equally in debt restructuring agreements (G-10, 1996; G-22, 1998).

\section{Related Literature.}

A number of authors have emphasized the importance of seniority in sovereign debt. Roubini and Setser (2004), for example, view "the absence of an enforceable priority structure for the sovereign's own debt" as "one of the basic problems $[\ldots]$ that arise in a debt restructuring". Dooley (2000) emphasizes the conflict between official and private lenders in the competition for repayment, i.e., the question of the seniority of the official sector. As documented in section 2, practioners pay a great deal of attention to the implicit seniority status of the different types of sovereign debt.

By comparison, the formal analysis of seniority in sovereign debt is relatively underdeveloped. Kletzer (1984) analyzes the equilibrium of the sovereign debt market when creditors do not observe the borrower's total indebtedness. Cohen (1991, chapter 4) presents a 3-period model of sovereign debt dilution and notes that the resulting inefficiency is aggravated by the absence of a bankruptcy regime for sovereigns. Detragiache (1994) ventures that the lack of formal seniority in sovereign debt, although a potential source of inefficiency, may paradoxically help in disciplining sovereigns from playing creditors against each other in debt restructuring negotiations. Tirole (2002, chapter 4) discusses the contracting externalities that may arise in the issuance of sovereign debt and mentions seniority as a possible solution to this problem.

The inefficiencies resulting from nonexclusivity in debt contracts have long been noted in the corporate finance literature. Fama and Miller (1972, chapter 4) provide an early discussion of how lenders can protect themselves from dilution by making their loans senior. White (1980) and Schwartz (1989) analyze 
how priority rules can protect against dilution. Bizer and DeMarzo (1992), on the other hand, show that seniority is not a perfect antidote to the nonexclusivity problem in the presence of debtor's moral hazard. Bisin and Rampini (2004) provides an analysis of bankruptcy regimes that is related to ours. In their paper, the institution of bankruptcy is welfare-improving because it alleviates the incentives problem resulting from the non-exclusivity of financial contracts. It achieves this benefit, furthermore, by enforcing the seniority of early lenders.

The paper is structured as follows. Section 2 reviews some stylized facts on sovereign debt that motivate the theoretical analysis in the rest of the paper. Section 3 gives the main assumptions of the model. Section 4 shows how the nonrenegotiability of debt can make it effectively senior. Sections 5 and 6 analyze the equilibrium when the government respectively can and cannot commit not to dilute its debt. Section 7 shows how non-renegotiable debt can be used to forestall dilution, as well as the efficiency costs involved. Section 8 draws some normative implications from the theory, highlighting in particular the welfare benefits of establishing de jure seniority in sovereign debt.

\section{Evidence}

This section presents evidence suggesting that there is an implicit seniority structure for sovereign debt, and that this structure is related to the perceived difficulty with which debt can be restructured. The implicit seniority in sovereign debt is an understudied topic, on which there has been very little empirical research. This section relies mainly on the facts reported in Zettelmeyer (2003) as well as the financial press.

The de facto seniority structure of sovereign debt is, for one thing, apparent from the different treatment of different classes of creditors in a default. The differential treatment of claims has been a characteristic of most debt restruc- 
turings that have taken place over the last 25 years (beginning with the debt renegotiations and write-downs of the 1980s and the Brady plan and continuing with the more recent debt restructurings in Russia, Ukraine, Pakistan, Ecuador and Uruguay). This differential treatment has not only taken the form of entirely excluding some debts (in particular, multilateral official debt) from debt restructurings, but also of negotiating more favorable deals for subclasses of private claims. Thus, for example, the "Brady deals" that settled the debt crises of the 1980s restructured bank loans but not international bonds (Merrill Lynch, 1995).

More recently, the composition of sovereign debt has shifted away from syndicated bank loans, which were the dominant form of lending in the 1970s and 1980s, towards bond finance (see Figure 1). While there is no single cause that explains this change in composition, one reason, undoubtedly, has been the perception, following the debt crises of the 1980s and the Brady deals, that syndicated bank loans were too easy to restructure. In valuing the new bond issues, at least some lenders have factored in a lower risk of restructuring of international bonds. To the extent that these bond issues were widely dispersed, they were perceived to be more difficult to restructure, and therefore less likely to be restructured in a debt crisis:

There are several things that make international bonds much harder to restructure than loans. First, they typically involve many more investors than do loans, even syndicated loans. Second, they may be in bearer form so investors may be untraceable. (Euromoney ${ }^{6}$, October 1999).

The recent debt crises and defaults of Russia and Argentina have highlighted just how difficult comprehensive debt restructuring negotiations can be, when

\footnotetext{
${ }^{6}$ Michael Peterson, "A crash course in default", Euromoney (October 1999), 47-50.
} 
they involve hundreds of thousand different bondholders with a wide variety of objectives.

During most of the 1990s the differential treatment of sovereign claims has followed a pattern that is consistent with an implicit seniority of international bonds over international bank loans. A total of 93 sovereigns have defaulted on their syndicated bank loans since 1975, including 20 that had bonds outstanding at the same time as their bank loans were in default. Yet, only 9 out of these 20 sovereigns also defaulted on their bonds, and the others serviced them in full (Standard and Poor's, 2003).

The restructuring of Russian sovereign debt (August 1998-August 2000) is typical of this pattern. Domestic debt and Soviet era London and Paris Club debts have been restructured (with international bank creditors accepting a debt exchange involving a 40 percent reduction in the present value of their claims), while Eurobonds have been left untouched. Market participants have viewed this latest Russian debt restructuring episode as further corroboration of the sovereigns' tendency of treating creditors differently according to their power of nuisance:

defaulters will always try to pick off the weakest creditors first. Russia has specialized in playing off one class of creditors against another, first by defaulting on its domestic debt while keeping up its Eurobond payments and more recently by attempting to restructure Soviet-era debt (Euromoney, October 1999, p. 48).

Market participants were also well aware that such behavior resulted in an implicit seniority structure affecting the pricing and valuation of debt:

It is that implicit seniority which, in part, explains why bonds have become such favoured instruments for countries raising debt in 
recent years, says Ernesto Martinez Alas, and analyst at Moody's. (Euromoney, October 1999, p. 50)

The majority of governments treated bonds as being effectively senior to bank loans, and they did so with the tacit consent of bank creditors. (Standard and Poor's, 2003)

The implicit seniority structure created by the Brady deal has been undermined by the debt restructuring of Pakistan (1999-2001). For the first time, Pakistan was pressured to demand comparable concessions from bond holders as from banks under the Paris Club deal, which itself was inspired by the new policy shift towards greater private sector involvement, advocated in the Rey Report (1996). Pakistan ended up restructuring bilateral official debt, bank claims and - for the first time - Eurobonds, but not domestic debt. Although the amount of Eurobonds involved was small (they accounted for less than 2 percent of Pakistan's external debt), this debt restructuring significantly altered the market's perception of the implicit seniority structure in international sovereign debt. Indeed, the announcement, in January 1999, that Pakistan would be forced to restructure its Eurobonds, triggered a rise in international bond spreads issued by emerging market governments other than Pakistan in the order of 25 to 95 basis points (Zettelmeyer, 2003).

Ever since the Pakistan restructuring and the official sector's perceived shift in policy towards private sector involvement (especially for small countries), market confidence that bonds hold priority over bank loans has been shattered. Two recent restructuring episodes, involving Ecuador in 2000, and Uruguay in 2003, where bond issues have been restructured but bank loans have been left untouched, have further eroded market beliefs. Perhaps in reaction to this shift in policy, innovative clauses have been introduced in new bond issues, that attempt to strengthen their de facto seniority. For example, one of the two Eu- 
robonds that creditors were offered in Ecuador's 2000 debt exchange contained a "principal reinstatement" clause, which provided for an automatic upward adjustment in principal in the event of a default. The face value of the bond holder's claim was to rise by a given amount in the event that Ecuador defaulted on the new bonds after the restructuring. Thus, incumbent bondholders received (temporary) protection from dilution that might result from new debt issuance.

This discussion points to several stylized facts that the theory in this paper will attempt to capture and explain:

- sovereigns do not default in the same way on different classes of debt instruments and this selectivity generates an implicit seniority between debt classes;

- seniority seems related to structural features of sovereign debt that make it more or less easy to renegotiate with creditors;

- international investors are aware of this implicit seniority structure and pay close attention to potential shifts in its determinants;

- the composition of international sovereign debt tends to shift to the class of instruments that is perceived as senior at a given point in time.

The remainder of this paper develops a model of sovereign debt, in a world without IMF bailouts, where, we believe, the two major moral hazard problems are strategic defaults and debt dilution by sovereigns. We not only model ex-post debt dilution, as has already been done by others, but we also characterize for the first time the optimal ex-ante debt structure, or de facto seniority structure. We show in particular that, in an effort to commit to limited debt dilution, sovereigns make their ex-ante debt contracts excessively difficult to restructure. We conclude from our analysis that a policy intervention that would make seniority and priority in sovereign debt legally enforceable would at the same time eliminate the distortion towards excessively hard debt and prevent 
overborrowing when sovereigns are approaching financial distress.

\section{The Model: assumptions}

We consider a small open economy over three periods with a single homogenous good that can be consumed or invested. The representative resident of this economy may raise funds from the rest of the world by issuing (sovereign) debt in the first period $(t=0)$. This debt is to be repaid in the next two periods $(t=1,2)$. The funds raised in the first period can be used for consumption or investment purposes.

To keep the analysis as tractable as possible we specify the following simple form for the utility function of the representative resident:

$$
U=V(g)+c_{1}+c_{2}
$$

where,

1. $c_{1}$ and $c_{2}$ denote the consumption levels of the representative resident in periods 1 and 2 respectively, and

2. $V(g)$ represents the gross present value of funds $g$ raised at time 0 by issuing debt. This value may be generated through additional consumption at $t=0$ or through public investment in infrastructure, health, schooling, etc. We do not need to specify exactly how the money raised is spent. We shall assume that $V^{\prime}(g)>0$ and $V^{\prime \prime}(g)<0$.

The representative resident produces stochastic output $y_{1}$ and $y_{2}$ in respectively periods 1 and 2 . The probability distribution functions over output in each period are given by $f_{1}($.$) and f_{2}($.$) . It is convenient, but not essential,$ to think of the respective outputs in periods 1 and 2 as independently distributed. We also make the inessential simplifying assumption that the realization 
of output in both periods, $y_{1}$ and $y_{2}$, is known in period $1^{7}$. We normalize the country's output in period $t=0$ to $y_{0}=0$. The sovereign acts on behalf of the representative resident and maximizes her welfare ${ }^{8}$.

Under autarky this representative resident would only be able to achieve a welfare level of

$$
E\left[U_{A}\right]=E\left[y_{1}\right]+E\left[y_{2}\right]=y_{1}^{e}+y_{2}^{e} .
$$

By borrowing from the rest of the world she may be able to enhance her welfare. We shall take it that the sovereign debt market is perfectly competitive and that the equilibrium riskless interest rate is equal to zero. But that is not to say that the sovereign debt market is perfectly efficient. Indeed, as we already hinted at, two forms of moral hazard limit the efficiency of the sovereign debt market in our model: the classical willingness-to-pay problem in sovereign lending (Eaton and Gersovitz, 1981) and, debt dilution where the sovereign reduces the value of outstanding debt by taking out new risky debt.

If sovereign debt markets were perfectly efficient and the sovereign were able to perfectly commit to repaying its debts up to its ability to repay, and also to commit not to take out new debt in periods 1 and 2 , then it would raise an optimal amount of funds, $g^{*}$, in period 0 given by the first-order condition for efficient borrowing:

$$
V^{\prime}\left(g^{*}\right)=1
$$

The sovereign would raise funds up to the point where the marginal benefit of an extra unit of funds is equal to the marginal cost of borrowing (which is always 1

\footnotetext{
${ }^{7}$ This is a common simplifying assumption made in the corporate finance literature (see, for example, Hart and Moore, 1998). If the realization of $y_{2}$ were not perfectly known in period 1 , the only difference in our analysis would be a slightly more involved decision problem for the sovereign in period 1. Generalizing our model to allow for this uncertainty would result in a more complex analysis without yielding any additional insights.

${ }^{8}$ In Bolton and Jeanne (2002) we model the issuing country government as a self-interested agent and begin to explore the implications for sovereign lending of the presence of this agency problem. See also Chang (2002) for a related analysis.
} 
given our assumption that world interest rates are equal to zero). This level of borrowing is our efficiency benchmark. If the sovereign ends up borrowing more than $g^{*}$ we shall say that there is over-borrowing and if it ends up borrowing less we shall say that there is under-borrowing.

The Modigliani-Miller theorem tells us that the first-best efficient repayment stream is indeterminate and that any agreed repayment stream, with an expected value of $g^{*}$ would be equivalent. To focus our analysis squarely on the design of debt renegotiability, we shall allow the issuer to only issue long-term debt maturing in period 2. In a follow-up paper we also explore the optimal debt-maturity structure by allowing the sovereign to issue any combination of short-term debt (maturing in period 1) and long-term debt. Here, we shall consider two forms of debt that the sovereign can issue: renegotiable debt (or $r$-debt) and non-renegotiable debt (or $n$-debt). Renegotiable debt and non-renegotiable debt can be interpreted as respectively syndicated bank loans and bonds (Gertner and Scharfstein, 1991; Lipworth and Nystedt, 2001), or as bonds with exit consents and collective action clauses versus bonds without such clauses ${ }^{9}$. We shall allow the sovereign to issue any combination of r-debt and n-debt.

The sovereign may issue debt in period 0 to finance the expenditure $g$, and again in period 1 to finance consumption $c_{1}$. We respectively denote by $D_{02}^{r}$ and $D_{02}^{n}$ the amount of r-debt and n-debt that the sovereign promises to repay in period 2 when it issues debt in period 0. Similarly, we denote by $D_{12}^{r}$ and $D_{12}^{n}$ the promised repayments on new debt issued in period 1 . In period 2 the sovereign' s liabilities of respectively r-debt and n-debt coming to maturity are therefore:

$$
D_{2}^{r}=D_{02}^{r}+D_{12}^{r},
$$

\footnotetext{
${ }^{9}$ See Eichengreen (2003) for a discussion of the role of Collective Action Clauses in sovereign debt restructuring, and Buchheit and Gulati (2000) for a discussion of exit consents in sovereign bond exchanges.
} 
and

$$
D_{2}^{n}=D_{02}^{n}+D_{12}^{n},
$$

and the sovereign's total liabilities are

$$
D_{2}=D_{2}^{r}+D_{2}^{n}
$$

The promise to repay $D_{2}$ is credible only if it is in the sovereign's interest to repay ex post. We follow the sovereign debt literature by assuming that the sovereign repays its debts only as a way of avoiding a costly default. Like Sachs and Cohen (1982) and Obstfeld and Rogoff (1996), we model the cost of default as a proportional output loss, $\gamma y_{2} \cdot{ }^{10}$

Critically for our analysis we decompose this cost into two components:

$$
\gamma y_{2}=\rho y_{2}+\lambda y_{2}
$$

The first component is a deadweight cost that the country must bear whenever it fails to repay its debt in full (it can be interpreted as a reputational cost of default, or a collateral output loss resulting from capital flight or a banking crisis, for example). The second component is a sanction that creditors may impose or waive (the output loss resulting from litigation by creditors in foreign courts

\footnotetext{
${ }^{10} \mathrm{It}$ is generally assumed in the literature that the cost of defaulting is the same whether the sovereign defaults in full or whether it repays part of its debt. This is a somewhat extreme assumption, but it is a more plausible assumption than another extreme assumption that comes to mind, by which default costs are only proportional to the size of the default. Concretely, this alternative assumption would specify default costs of $\min \left\{\gamma s, y_{2}-R\right\}$ for a shortfall in repayments $s=\left(D_{2}-R\right)$. It is easy to see that under this assumption the sovereign always defaults in full when $\gamma<1$. And when $\gamma \geq 1$ then the sovereign only defaults if it is unable to repay all its debts $\left(y_{2}<D_{2}\right)$. And then it always repays all it can. This assumption clearly gives rise to unrealistic and implausible sovereign default behavior.

Reality is likely to lie somewhere in between these extreme assumptions and one might want to consider the more general default cost function $\gamma(s) y_{2}$, where $\gamma(s)$ is increasing in the repayment shortfall $s$ from zero to a maximum value, $\bar{\gamma}<1$. If $\gamma(\cdot)$ is a concave function then, when the sovereign is better off defaulting, it is optimal to always default in full and incur the cost $\bar{\gamma} y_{2}$. Our analysis would be virtually unchanged if we allowed for this more general default cost function.

On the other hand, if $\gamma(\cdot)$ is a convex function then there may be an interval of output realizations $y_{2}$ for which it is optimal for the sovereign to repay some of its debt obligations when it defaults. Allowing for this possibility, while adding more realism to the model would not alter the main thrust of our analysis. It would however require a more involved analysis in places.
} 
or from trade sanctions, for example). The various default costs considered in the literature on sovereign debt fall in one or the other category (see Eaton and Gersowitz, 1981, for the first type, and Bulow and Rogoff, 1989, for the second type). The first component is a clear deadweight cost of default. It is an output loss incurred by the contracting parties following a default. The second component, on the other hand, is a cost that can be avoided if the creditors can be persuaded to waive sanctions in debt renegotiations following default.

Whether creditors can be persuaded to lift the sanctions depends on whether debt is of the renegotiable or nonrenegotiable type. We assume that the holders of renegotiable debt (the r-creditors for short) can be coordinated at no cost ${ }^{11}$ around a debt restructuring agreement in which they consent to lift the sanction $\lambda y_{2}$ in exchange of a payment $\eta$. In contrast, such an agreement is impossible to reach with the holders of n-debt (the n-creditors), since they are widely dispersed and the debt contract does not include any mechanism allowing them to collectively agree to a debt restructuring plan. The n-creditors automatically impose the sanction if they are not fully repaid. This inefficiency captures the idea that when debt holders are widely dispersed it will be difficult to reach an acceptable agreement to everyone in a timely fashion and to avoid free riding by hold-out creditors ${ }^{12}$.

More formally, the sequence of actions in period 2 is as depicted in Figure 2. First, the government decides whether to repay its debts fully or default. Following a default, the r-creditors make a take-or-leave repayment demand of $\eta \leq D_{2}^{r}$. The government then accepts or rejects the r-creditors' demand.

\footnotetext{
${ }^{11}$ An alternative interpretation of our assumptions is that if there is a deadweight cost of renegotiating $\mathrm{r}$-debt, this cost is already subsumed in the "reputation cost" $\rho y_{2}$.

12 This inefficiency may be incurred even though it hurts n-creditors collectively because of a free-rider problem-like in Diamond and Rajan (2001) or Jeanne (2004). For example, individual litigating creditors could hope to seize some collateral. If they litigate in an uncoordinated way, these creditors might impose an output cost on the country that is much larger than the value of collateral that they can seize. Similarly, the n-creditors may be unable to accept a voluntary decentralized debt exchange or repurchase, even an efficient one, because of free-riding by holdouts (Bulow and Rogoff, 1991).
} 
Acceptance implies a partial default on r-debt, in which the r-creditors receive a fraction $\eta / D_{2}^{r}$ of their claims and the n-creditors are fully repaid. Rejection implies a full default in which the government repays nothing to its $r$-and ncreditors and incurs the sanction $\lambda y_{2}$. If the offer is rejected r-creditors impose sanctions on the sovereign, in which case the sovereign might as well default on n-debt, as there is no further cost in defaulting on all debts. Figure 2 gives the payoffs of the government and its creditors under full repayment, and partial and full default.

The difference between the two types of creditors relates to their ability to act collectively, not in the size of the sanction they can impose on the debtor or in their bargaining power. The n-creditors, as a group, cannot negotiate a debt reduction with the sovereign. By contrast, the r-creditors can bargain collectively. They have all the bargaining power, since they make a take-or-leave offer. They will ask for a full repayment, $\eta=D_{2}^{r}$, whenever possible, and for a lower repayment only to preempt a costly sovereign default that reduces the total repayment (to zero in our model).

This formulation captures in a simple way the fact that some types of sovereign debt are more difficult to restructure than others because of coordination problems between creditors, and that these types of debt tend to get restructured less often. Here, we simplify the situation in the extreme by assuming that n-debt is impossible to restructure. This assumption trivially implies that debt restructuring, if it occurs, involves r-debt only. This is a simple representation of the selective defaults which, as documented in the previous section, are one way that sovereigns discriminate between different classes of creditors in the real world.

Admittedly, our model leaves aside important complications that arise in real world sovereign defaults. It would be more realistic to let the sovereign negotiate simultaneously with both types of creditors. However, the modeling of 
debt restructuring negotiations involving both $\mathrm{r}$-debt and $\mathrm{n}$-debt is not obvious a priori. Especially, finding a way of capturing the idea that n-debt is more difficult to renegotiate in a model of trilateral bargaining is far from straightforward $^{13}$. Here, we abstract from these complications by assuming that the only way that the sovereign discriminates between its creditors is through selective defaults. We believe that this is an acceptable simplification, given that the focus of our analysis is on understanding the implications of unequal creditor treatment for the ex ante equilibrium of the debt market, rather than on accounting for all the different ways in which creditors can be treated unequally ex post.

To summarize, the timing of moves and events in our model is as follows: The sovereign begins by raising $g$ in period 0 in the form of debt repayable in period 2. In period 1 the sovereign can issue more debt also repayable the next period. We assume that these borrowing decisions are made sequentially and that the sovereign cannot commit to its future debt management in period 0 . This assumption seems reasonable as a benchmark, since in the real world there is no obvious way a sovereign can commit not to issue debt in the future. In period 2 output $y_{2}$ is realized and debts are repaid. In case of a default the debt restructuring continuation game described above is triggered. Finally, the representative resident consumes the remaining output and the game ends.

In the following sections our ultimate goal is to characterize the optimal debt structure chosen by the sovereign in period 0 . We proceed in several steps. Section 4 begins with the characterization of equilibrium repayment behavior in period 2. Section 5 shows that if commitment were possible, the government would issue r-debt only in period 0 . Section 6 shows that such a strategy is not time consistent as the government is then tempted to dilute the r-debt in

\footnotetext{
${ }^{13}$ Intuitively, coordination problems are likely to enhance the leverage of n-creditors in the debt restructuring process, thus reproducing in full defaults the kind of effective priority that we obtain here through the selectivity of defaults.
} 
period 1. Section 7 derives the equilibrium (time consistent) strategy, which under fairly general conditions is to issue $\mathrm{n}$-debt in period 0 .

\section{Strategic Default}

In this section we determine when the sovereign repays its debts in period 2 and when it defaults, taking $D_{2}^{r}$ and $D_{2}^{n}$ as given. The debtor country may repay all its debts, default partially, or fully. Default results in an unavoidable output loss of $\rho y_{2}$. If the government defaults on its n-debt an additional output loss of $\lambda y_{2}$ is incurred.

Let us assume that the sovereign defaults. Is the default full or partial? This depends on whether the r-creditors can make an acceptable offer $\eta \geq 0$ to the sovereign. In the event of a partial default on r-debt, the sovereign's payoff is

$$
(1-\rho) y_{2}-\eta-D_{2}^{n}
$$

if it accepts the offer $\eta$ from r-creditors. Should the offer $\eta$ be rejected, there is a full default and the sovereign's payoff is $(1-\rho-\lambda) y_{2}$. The r-creditors can make an acceptable offer, therefore, if and only if,

$$
D_{2}^{n} \leq \lambda y_{2}
$$

The holders of r-debt always prefer a positive repayment $\eta \geq 0$ to a full default

with no repayment. Since they have all the bargaining power, they therefore set $\eta$ at the level that makes the sovereign indifferent between a partial and a full default, or

$$
\eta=\lambda y_{2}-D_{2}^{n}
$$

By contrast, if $D_{2}^{n}>\lambda y_{2}$ the r-creditors cannot make an acceptable offer and the default must be full. The sovereign is better off defaulting on all its debts than selectively defaulting on r-debt. Conditional on a default, therefore, the default is partial if $y_{2}$ is larger than $D_{2}^{n} / \lambda$, and full otherwise. 
When is the sovereign better off defaulting? To answer this question we only need to compare the sovereign's payoff under no default,

$$
y_{2}-D_{2}^{r}-D_{2}^{n},
$$

and its payoff under partial or full default, which in either case is

$$
(1-\rho-\lambda) y_{2}
$$

since all renegotiation rents are extracted by r-creditors. Thus, the sovereign defaults if and only if period 2 output falls below a threshold:

$$
y_{2}<\frac{D_{2}^{r}+D_{2}^{n}}{\rho+\lambda} .
$$

A partial default, therefore, occurs if and only if conditions (1) and (2) are met. These two conditions, in turn, are compatible only if $\frac{D_{2}^{n}}{\lambda}<\frac{D_{2}^{n}+D_{2}^{r}}{\rho+\lambda}$, or if

$$
\frac{D_{2}^{n}}{\lambda}<\frac{D_{2}^{r}}{\rho}
$$

Ordering these cases in terms of $y_{2}$ then gives the following result:

Proposition 1 The sovereign's debt repayment strategy is as follows:

(i) full repayment: if $y_{2} \geq \frac{D_{2}^{n}+D_{2}^{r}}{\gamma}$. The sovereign fully repays its renegotiable and non-renegotiable debt.

(ii) partial default: if $\frac{D_{2}^{n}}{\lambda} \leq y_{2}<\frac{D_{2}^{n}+D_{2}^{r}}{\gamma}$. The sovereign fully repays its non-renegotiable debt and repays $\lambda y_{2}-D_{2}^{n}$ to the holders of renegotiable debt.

(ii) full default: if $y_{2}<\frac{D_{2}^{n}}{\lambda}$. The sovereign defaults on all outstanding debts and repays nothing.

Proof. See discussion above.

Notice that the parties' period-2 payoffs have been specified under the assumption that the sovereign consumes the entire period-1 output $y_{1}$ in period 1. It turns out that there is no loss of generality in our model in assuming 
that the sovereign consumes net output as it accrues. The reason is that the sovereign is assumed to be risk neutral. Moreover, if the sovereign decided to save part or all of $y_{1}$ until period 2 there would be no change in the sovereign' s debt repayment decision. Indeed, the sovereign's decision to repay the debt is entirely driven by the cost of default, which is proportional to period-2 output, and is therefore not affected by any savings decision in period $1^{14}$.

This proposition clarifies the notion that non-renegotiable debt is effectively senior to renegotiable debt. In the case of partial default, the allocation of the repayment between $\mathrm{r}$-creditors and $\mathrm{n}$-creditors is the same as if the latter enjoyed strict seniority over the former. Because of this effective seniority, n-creditors have a larger expected recovery ratio than r-creditors, so that the interest rate spread should be lower on n-debt than on r-debt.

\section{Optimal debt structure under commitment}

What is the ex-ante optimal combination of n-debt and r-debt? The answer to this question depends on whether the government can commit not to dilute debt issued in period 0 with new debt issued in period 1 . In this section we assume that the government can credibly commit not to dilute its initial debt. We thereby isolate the only remaining moral hazard problem in our model: the classic willingness-to-pay problem. This assumption, although not realistic, provides a convenient benchmark for the case with no commitment, where dilution is possible.

It is not difficult to see that in equilibrium, the sovereign would want to commit not to issue new debt in period 1. Indeed, for any funds $g_{1} \geq 0$ raised in period 1 by issuing new debt, the country's ex ante welfare, taking the lenders'

\footnotetext{
${ }^{14}$ This is an important simplifying feature of our model, which is specific to the sovereign debt problem. In a corporate debt problem, in contrast, any accumulated cash-flow can be seized by creditors upon default. Therefore, the decision on how much cash-flow to accumulate in earlier periods has an important bearing on the corporate borrower's future default decision.
} 
participation constraint to be binding, is given by

$$
U_{0}=V(g)-g+E_{0}\left(y_{1}+y_{2}\right)-E_{0}\left(\ell \mid g+g_{1}\right),
$$

where $\ell$ is the deadweight cost of default. Note that the funds raised in period 1 only appear in the term $E_{0}\left(\ell \mid g+g_{1}\right)$, as any benefit derived by consuming $g_{1}$ in period- 1 entails expected repayments to creditors in period 2 that exactly offset $g_{1}$ in period 2. Thus, the only effect of issuing debt in period 1 is to reduce ex ante welfare by raising the likelihood of default and deadweight costs $E_{0}\left(\ell \mid g+g_{1}\right)$.

We are now in a position to establish that when there is no debt dilution it is optimal for the sovereign to only issue r-debt.

Proposition 2 Let $[\underline{y}, \bar{y}]$ denote the support of $f_{2}(\cdot)$. Under a pure willingnessto-repay problem the sovereign's debt structure is such that a full default never occurs in equilibrium: $D_{2}^{n}<\lambda \underline{y}$. If $g^{*}>\gamma \underline{y}$ the sovereign under-borrows in period 0.

Proof. See appendix.

This proposition defines the sense in which the renegotiable and nonrenegotiable debts can be viewed as respectively "good" and "bad" in our model. If the government could commit not to dilute, it would always keep n-debt at a level where full default is impossible. The equilibrium debt structure is not uniquely defined in general, but one debt structure that is always optimal is pure r-debt. This striking result is driven by our assumptions that n-debt involves a higher deadweight cost of default of $\lambda y_{2}$ and that r-creditors are able to appropriate the entire amount $\lambda y_{2}$ in debt renegotiations following default. In the other extreme case where the bargaining power in debt renegotiations is entirely in the hands of the sovereign it may be strictly optimal for the sovereign to issue 
a strictly positive amount of n-debt as a way of commiting to making higher debt repayments ${ }^{15}$. In general, for intermediate bargaining powers it may be optimal to issue an amount of n-debt that just balances the ex-ante commitment benefits and the ex-post deadweight costs of default.

We focus on the extreme case where r-creditors have all the bargaining power in renegotiation for expositional reasons. In this case there is a clear prediction on the optimal form of debt in a pure willingness-to-pay problem. As we shall see in the following sections, however, in the presence of both a willingness-topay and a dilution problem it is generally optimal for the sovereign to issue a strictly positive amount of n-debt as a way of mitigating dilution.

\section{Dilution with renegotiable debt}

We now relax the assumption on commitment made in the previous section and characterize the sovereign' s optimal dynamic borrowing policy, when it is restricted to issuing r-debt only. We begin by observing that the commitment not to dilute is time-inconsistent, and we show that the time-consistent borrowing strategy involves both excessive defaults and a lower level of expenditure $g$ than

\footnotetext{
${ }^{15}$ To see this, compare $\mathrm{r}$-debt and $\mathrm{n}$-debt required to raise the same amount $g$ in the following example, where the sovereign has all the bargaining power and $y_{2}$ is uniformly distributed in $[0, \bar{y}]$. Under $\mathrm{r}$-debt the sovereign now defaults whenever $y_{2} \leq \frac{D^{r}}{\rho}$, while under n-debt it only defaults when $y_{2} \leq \frac{D^{n}}{\gamma}$. Given that creditors receive nothing in a default, the sovereign must set $D^{r}$ and $D^{n}$ such that

$$
g=D^{r}\left(1-D^{r} / \rho \bar{y}\right)=D^{n}\left(1-D^{n} / \gamma \bar{y}\right) .
$$

Raising n-debt instead of r-debt is preferable if this yields a lower expected deadweight loss,

or

$$
\lambda \int_{0}^{\frac{D^{n}}{\gamma}} y_{2} \frac{d y_{2}}{\bar{y}}<\rho \int_{\frac{D^{n}}{\gamma}}^{\frac{D^{r}}{\rho}} y_{2} \frac{d y_{2}}{\bar{y}},
$$

$$
\frac{\left(D^{n}\right)^{2}}{\gamma}<\frac{\left(D^{r}\right)^{2}}{\rho},
$$

which is true because of $(5)$ and $D^{r}>D^{n}$.

Unfortunately, the general case where the sovereign's bargaining power is arbitrary and $f_{2}(\cdot)$ is a general distribution is not straightforward to characterize. This is why we work with the simple benchmark where the sovereign has no bargaining power, when it is easy to see that r-debt is optimal.
} 
under commitment.

Suppose that the sovereign issues r-debt $D_{02}^{r}$ in period 0 and consider the sovereign's incentive to issue new r-debt in period 1 . The new debt is a promise to repay $D_{12}^{r}$ (on top of $D_{02}^{r}$ ) in period 2 . If the realization of output $y_{2}$ observed by the sovereign in period 1 is such that $D_{02}^{r}<\gamma y_{2}$ the country is solvent absent any new debt issue. By issuing a new debt claim $D_{12}^{r}$ the representative resident's payoff is then:

$$
\begin{aligned}
U_{1}= & y_{1}+D_{12}^{r}+y_{2}-\left(D_{02}^{r}+D_{12}^{r}\right) \quad \text { if } D_{02}^{r}+D_{12}^{r} \leq \gamma y_{2}, \\
& \quad \text { and } \\
U_{1}= & \left(y_{1}+\frac{D_{12}^{r}}{D_{02}^{r}+D_{12}^{r}} \lambda y_{2}\right)+(1-\gamma) y_{2} \quad \text { if } D_{02}^{r}+D_{12}^{r}>\gamma y_{2} .
\end{aligned}
$$

(Note that the payoff from the public expenditure $g$ is sunk in period 1 and can be ommitted.)

The first expression corresponds to the case where the amount of new debt $D_{12}^{r}$ is small enough to keep the country solvent. The country will then repay $D_{12}^{r}$ with certainty, so that it is able to raise an amount $g_{1}=D_{12}^{r}$ from the competitive capital markets. Since the country entirely repays $D_{12}^{r}$ in period 2, such additional borrowing in period 1 is a wash and does not affect welfare in any way. We assume then that when indifferent the country chooses to issue no new debt.

The second expression corresponds to the case where the amount of new debt is large enough to force the country into default in period 2. The default is always followed by a renegotiation since there is no n-debt. Then the proceeds of the new loan are equal to the total repayment conditional on a default, $\lambda y_{2}$, times the share of the new creditors in the aggregate claims, $D_{12}^{r} /\left(D_{02}^{r}+\right.$ $\left.D_{12}^{r}\right)$. In practice, sovereign debt restructuring often takes the form of a pro-rata "haircut" across multiple debt issues, as we are assuming here. It is precisely the lack of clear seniority in debt renegotiations of existing debt over newly issued 
debt that is the source of debt-dilution moral-hazard in sovereign lending ${ }^{16}$.

Because of this pro-rata haircut, the sovereign's payoff at $t=1$ is now strictly increasing with $D_{12}^{r}$. Each additional dollar of debt costs nothing to the representative resident (who loses $\gamma y_{2}$ in a default anyway), and can be sold at a positive price to the new lenders. Each additional dollar of new debt issued, then comes entirely at the expense of the long-term creditors who see their claims diluted.

Conditional on a default, the country's welfare is then bounded above by

$$
y_{1}+\lambda y_{2}+y_{2}(1-\gamma)=y_{1}+y_{2}(1-\rho)
$$

We shall assume for simplicity that this payoff can always be attained by issuing a sufficiently large new debt $D_{12}^{r}$ in period 1 .

In equilibrium, the country does not dilute its initial debt $D_{02}^{r}$ if and only if the resulting welfare, $\left(y_{1}+y_{2}-D_{2}^{r}\right)$ is higher than the welfare under dilution, $y_{1}+y_{2}(1-\rho)$. This defines an upper bound for initial debt above which the sovereign will have an incentive to dilute the initial debt:

$$
D_{02}^{r} \leq \rho y_{2}
$$

Note that while condition (6) was derived under the assumption that the country was solvent $\left(D_{02}^{r} \leq \gamma y_{2}\right)$, an insolvent sovereign, knowing that the default cost will have to be paid anyway, systematically dilutes its long-term creditors. So condition (6) is both necessary and sufficient for dilution not to occur. We summarize our discussion of the incentives towards debt dilution in the proposition below.

Proposition 3 The sovereign dilutes its r-debt in period 1 and defaults in pe-

\footnotetext{
${ }^{16}$ In the case of corporate debt, debt dilution moral hazard can be eliminated by making older debt senior to new debt. Subordination clauses or security agreements in debt contracts are enforceable in courts and are routinely included in corporate debt contracts (see Smith and Warner, 1979, for a description of the more common seniority protections in corporate debt). This is, however, not the case for sovereign debt.
} 
riod 2 if and only if period 2 output falls below a threshold

$$
y_{2}<\frac{D_{02}^{r}}{\rho} .
$$

Proof. See discussion above.

Increasing period 1 consumption through more borrowing in period 1 always comes at the cost of a reduced period 2 consumption. But, when output $y_{2}$ is relatively low then the gains from repaying $D_{02}^{r}$ and not defaulting are small. At that point it becomes tempting to borrow more and dilute the existing debt. More generally, the sovereign has a tendency to overborrow and dilute when it approaches financial distress ${ }^{17}$.

In equilibrium, debt dilution is, of course, anticipated and initial lenders will demand a higher repayment to compensate for such dilution. This will result in an even higher overall cost of borrowing, and therefore, in lower borrowing in period 0 . The equilibrium level of debt $D_{02}^{r}$ that is required in period 0 to finance a level $g$ of public expenditure under no commitment is easily derived. As the long-term creditors are repaid $D_{02}^{r}$ only if there is no dilution and get nothing otherwise they are only willing to lend an amount:

$$
g=D_{02}^{r} \int_{D_{02}^{r} / \rho}^{+\infty} f_{2}\left(y_{2}\right) d y_{2} .
$$

Suppose that $g$ is small enough that a solution $D_{02}^{r}(g)$ satisfying this equation exists. The country's ex-ante welfare is then given by:

$$
U_{0}=V(g)-g+E_{0}\left(y_{1}+y_{2}\right)-\rho \int_{0}^{D_{02}^{r}(g) / \rho} y_{2} f\left(y_{2}\right) d y_{2} .
$$

The last term on the right-hand-side of (9) is the agency cost of debt. It is strictly positive if $y_{2}$ falls below $D_{02}^{r}(g) / \rho$ with a strictly positive probability.

\footnotetext{
${ }^{17}$ If $y_{2}$ were uncertain in period 1 , the government would dilute when the probability of a default in period 2 conditional on no dilution exceeds a certain threshold.
} 
Welfare is lower under no commitment than under commitment, for any given level of $g$, by an amount

$$
\rho \int_{D_{2}(g) / \gamma}^{D_{02}^{r}(g) / \rho} y_{2} f_{2}\left(y_{2}\right) d y_{2},
$$

where $D_{2}^{r}(g)$ is the equilibrium debt repayment under commitment (this expression can be derived by taking the difference of (9) and (14)). This expression is positive for two reasons. First, if the risk premium on r-debt were the same under no commitment as under commitment (i.e., if $D_{02}^{r}(g)$ were equal to $D_{2}^{r}(g)$ ), welfare would be lower under no commitment because dilution results in more frequent defaults. Second, the risk premium is, of course, higher under no commitment: $D_{02}^{r}(g)>D_{2}^{r}(g)$ (compare (8) and (15)). The risk premium is larger under no commitment because lenders have to be compensated for the risk of dilution.

The only case in which the first-best is not distorted is if $\rho y_{2}$ is larger than $g^{*}$ with probability 1 . Then the government can borrow $D_{02}^{r}=g^{*}$ and repays with certainty. Otherwise the agency cost of debt is strictly positive, leading the government to reduce $g$ below the first-best level. We summarize this discussion in the proposition below.

Proposition 4 If $g^{*}>\rho \underline{y}$, the level of period 0 borrowing and welfare under no commitment are strictly below the levels of borrowing and welfare under a commitment not to dilute debt.

Proof. See discussion above.

\section{Non-renegotiable debt to forestall dilution}

We now derive the optimal dynamic borrowing strategy $\left(D_{02}^{r}, D_{02}^{n}, D_{12}^{r}, D_{12}^{n}\right)$ when the government can issue both r-debt and n-debt in periods 0 and 1 , and cannot commit not to dilute early lenders. 
The analysis proceeds along the following steps. First, we highlight the comparative advantage of n-debt, which is that it cannot be diluted. The holders of long-term n-debt are protected against dilution by their effective seniority. The sovereign, therefore, may make some of its long-term debt nonrenegotiable as a way of forestalling dilution.

The sovereign makes its long-term debt nonrenegotiable as long as the benefit of forestalling dilution dominates the cost of higher deadweight losses of default in period 2. The optimal debt structure depends on the specification and the parameters of the model. We show in section 7.2 that under a fairly general condition on the stochastic distribution of second period output $y_{2}$, it is optimal for the government to make its debt entirely nonrenegotiable.

\subsection{Dilution}

Expropriation of outstanding debt through dilution requires both a default and a debt restructuring. Intuitively, thus, a debt issue that is more difficult to restructure should also be more difficult to dilute. Such an issue is not only less vulnerable to a selective default but it may also get preferential treatment in a restructuring.

This intuition is captured in a stark way by our model, as n-debt cannot be diluted at all. An implication of Proposition 1 is that it is impossible to expropriate n-creditors who have lent in period 0 with a new round of lending in period 1 . The reason is simply that when period $0 \mathrm{n}$-creditors are not fully repaid, no other creditors are ${ }^{18}$. In contrast, renegotiable debt can be diluted by subsequent issues of either renegotiable or non-renegotiable debt.

Consider first dilution through new renegotiable debt issues. Dilution is

\footnotetext{
${ }^{18}$ This extreme outcome is driven by our assumption that the recovery value of debt is zero in a full default. If the recovery value of $n$-debt were positive, the $n$-debt issued in period 0 could be diluted in period 1 (by issuing more n-debt if n-creditors were effectively senior to r-creditors in the restructuring process). Even in this case, however, it would remain true that n-debt is diluted less often than r-debt.
} 
possible in period 1 only if $D_{02}^{n}<\lambda y_{2}$ (if not, investors will not provide any new loans since they know that there will be a full default in period 2). If the government issues new r-debt $D_{12}^{r}$ the representative resident's payoff is given by

$$
\begin{aligned}
U_{1} & =y_{1}+D_{12}^{r}+y_{2}-\left(D_{02}^{r}+D_{12}^{r}+D_{02}^{n}\right) \quad \text { if } D_{02}^{r}+D_{12}^{r}+D_{02}^{n} \leq \gamma y_{2}, \\
& =y_{1}+\frac{D_{12}^{r}}{D_{02}^{r}+D_{12}^{r}}\left(\lambda y_{2}-D_{02}^{n}\right)+(1-\gamma) y_{2} \quad \text { if } D_{02}^{r}+D_{12}^{r}+D_{02}^{n}>\gamma y_{2} .
\end{aligned}
$$

Given that $D_{02}^{n} \leq \lambda y_{2}$, the old n-debt will be fully repaid with certainty, and the only debt that can be diluted is the r-debt. The maximum benefit of dilution is achieved by completely diluting the old r-debt, which yields a payoff $U_{1}=$ $y_{1}+\left(\lambda y_{2}-D_{02}^{n}\right)+(1-\gamma) y_{2}=y_{1}+(1-\rho) y_{2}-D_{02}^{n}$. This is higher than the payoff under no dilution if and only if

$$
y_{2}<\frac{D_{02}^{r}}{\rho} .
$$

This condition is the same as (7), the condition for dilution when there is no n-debt.

Note that complete dilution of old $\mathrm{r}$-debt could also be achieved by issuing an amount $\lambda y_{2}-D_{02}^{n}$ of $\mathrm{n}$-debt. The payoffs to creditors are the same in both cases: $\mathrm{n}$-creditors receive all the pledgeable output and $\mathrm{r}$-creditors receive nothing. Thus, r-debt and n-debt are perfectly substitutable in diluting r-debt. To sum up, we have shown:

Proposition 5 If the country has issued non-renegotiable debt $D_{02}^{n}$ and renegotiable debt $D_{02}^{r}$ in period 0 , there is dilution in period 1 if and only if

$$
\frac{D_{02}^{n}}{\lambda}<y_{2}<\frac{D_{02}^{r}}{\rho} \text {. }
$$

Proof. See discussion above.

When can the government finance the first-best level of expenditure $g^{*}$ with an efficient, default-free debt structure? If $g^{*}<\gamma \underline{y}$, the government can implement the first-best outcome by issuing only n-debt $D_{02}^{n}=g^{*}$ and never 
defaulting on it. Alternatively, the government could issue a mixture of n-debt and r-debt, provided that the level of r-debt stays low enough to prevent dilution. As mentioned in section 6, a pure r-debt structure can also implement the first-best if $g^{*}<\rho \underline{y}$.

A contrario if,

$$
g^{*}>\gamma \underline{y}
$$

the first-best level of expenditure $g^{*}$ cannot be financed with a default-free debt structure. We assume that (11) is satisfied in the remainder of the analysis, so that debt dilution is a problem in equilibrium.

\subsection{When non-renegotiable debt dominates}

For any given level of expenditure $g$, the government chooses the debt structure to minimize the agency cost of debt. This choice involves a tradeoff between n-debt, which reduces the rate of dilution and the frequency of defaults, and r-debt, which entails a lower deadweight cost of default.

What is the optimal second-best debt structure? It is easy to see from the tradeoff described above that the answer to this question is not obvious in general. However, it is possible to show that generally the government issues a strictly positive amount of $\mathrm{n}$-debt in equilibrium.

Proposition 6 If $\underline{y} f_{2}(\underline{y})=0$, the sovereign issues $n$-debt in period 0 up to a level where the probability of a full default is strictly positive.

Proof. See the appendix.

The intuition behind this result is the following. Assume that n-debt is set in period 0 at the maximum level consistent with a zero probability of a full default. Then by issuing a small (first-order) additional amount of n-debt that will almost surely be fully repaid, the country can finance a first-order increase in $g$. If $\underline{y} f_{2}(\underline{y})=0$, the associated increase in the expected deadweight 
cost of a full default is of the second-order. The country, therefore, will issue more $\mathrm{n}$-debt in period 0 , up to a level where the probability of a full default is strictly positive. This is the weak form of what one might refer to as the Gresham law for sovereign debt: "bad" (non-renegotiable) debt always drives some "good" (renegotiable) debt out when there is a risk of dilution and the marginal deadweight cost of n-debt is not too large.

The optimal share of n-debt is difficult to pin down in general, but can be explicitly determined under the following assumption.

Assumption A1. $h(x) \equiv \int_{x}^{+\infty} f_{2}(y) d y /\left(x f_{2}(x)\right)$ is strictly decreasing with $x$ in the domain of $f_{2}(\cdot)$.

This assumption holds for a number of well known distributions, including the normal, the exponential and the uniform distributions. If the distribution of output satisfies this assumption then we obtain the following result.

Proposition 7 Under Assumption A1, a second-best debt structure is optimal if and only if

$$
\frac{D_{02}^{n}}{\lambda} \geq \frac{D_{02}^{r}}{\rho}
$$

The optimal debt structure is not uniquely determined. One optimal debt structure is pure $n$-debt $\left(D_{02}^{r}=0\right)$. For such debt structures there is no dilution in equilibrium

$$
D_{12}^{r}=D_{12}^{n}=0
$$

Proof. See appendix.

This is what one might refer to as the strong form of our Gresham law: under assumption A1, not only is n-debt present in equilibrium, but it completely crowds out r-debt. Assumption A1 is relatively weak but it is necessary for n-debt to unambiguously crowd out r-debt. In the appendix we provide a counterexample where the distribution of $y_{2}$ does not satisfy A1 (it is binomial) and it may be optimal for the government to issue some r-debt in equilibrium. 
The intuition behind assumption A1 is the following. When dilution occurs in equilibrium, substituting r-debt by n-debt for a given level of $g$ has two opposite effects on the agency cost of debt. On the one hand, the increase in the level of n-debt raises the probability of a full default and so the expected deadweight loss of default. On the other hand, reducing the level of r-debt lowers the incidence of dilution. Assumption A1 ensures that the second effect dominates because the probability that $y_{2}$ is just below the dilution threshold $D_{2}^{r} / \rho$ is not too low relative to the probability that $y_{2}$ is just above the threshold for full default, $D_{2}^{n} / \lambda$. Thus, it is always optimal for the sovereign to substitute r-debt by n-debt up to the point where dilution does not occur in equilibrium.

The benefits of nonrenegotiable debt are illustrated in Figure 4a-c for a numerical specification of the model that satisfies assumption A1: $V(g)=\sqrt{g}$, $\rho=1 / 3, \lambda=2 / 3, y_{1}=0$ and $y_{2}$ uniformly distributed in the interval $[0,1]$. Figure 4 a shows the equilibrium debt repayment $D_{2}$ on the $y$-axis as a function of the level of expenditure $g$ on the $x$-axis, under respective scenarios of full commitment, no commitment with r-debt, and with n-debt (the scenarios considered in sections 5, 6 and 7 respectively). Figure $4 \mathrm{~b}$ displays the interest rate $\left(D_{2}-g\right) / g$. As figure $4 \mathrm{~b}$ shows, under no commitment the interest rate is lower on n-debt. As is easy to see by now, the reason is that the dilution premium on r-debt exceeds the higher risk premium on n-debt due to the lower recovery value on n-debt. Figure 4c shows how ex ante welfare varies with $g$. Under no commitment, issuing $\mathrm{n}$-debt puts the economy close to the commitment equilibrium: switching from r-debt to n-debt offsets 60 percent of the decrease in $g$ and 70 percent of the welfare loss due to dilution. 


\section{Public Policy}

Our analysis has shown that sovereigns have an incentive to bias their debt structure towards debt that is harder to restructure as a way of achieving de facto seniority and thus limit the extent of debt dilution. A sovereign engages in this form of inefficient debt structuring because there is no easy way of implementing seniority de jure. In contrast to corporate debt, where courts generally enforce priority and seniority, there is no easy way of legally enforcing priority for sovereign debt.

If sovereign debt is inefficiently structured to make debt restructuring harder, is there a case for policy intervention, and if so, how should policy be designed to alleviate the severity of debt crises? We take up these questions in this section.

In response to the rapid growth of sovereign bond issues in the 1990s, and following the proclaimed change in the I.M.F.'s policy towards reduced bailouts and more debt restructuring in debt crises, there has been a growing call for policy intervention to facilitate debt restructuring. There is, however, still an ongoing heated debate on how deep this policy intervention should be. Many in the international community favor a more interventionist policy and have advocated that sovereign debt restructuring be modeled on existing practice in corporate bankruptcy. Others, including most institutional investors and some emerging market countries, favor a more limited intervention that would only involve smoothing the implementation of debt-exchanges and introducing majority voting clauses - the so-called "collective action clauses" (CAC) - to help restructure the payment terms of sovereign bonds. A consensus has emerged from this debate that at least a limited form of intervention, mainly in the form of CACs, would be desirable. The I.M.F.'s more interventionist sovereign debt restructuring mechanism (SDRM) has been shelved for now by the G-10, but it remains an option. Our analysis in this paper provides some simple answers to 
these complex policy questions. We begin our discussion with the more limited form of intervention, the so-called contractual approach.

\subsection{The contractual approach}

Under the contractual approach, sovereigns are encouraged to facilitate debt restructuring by including collective action clauses (CAC) in all their bond issues. These clauses allow for the reduction in the payment terms of a bond issue if a super-majority of bondholders (e.g., a 2/3 majority) approves a proposed haircut. If a debtor wants to renegotiate the payment terms of a bond issue with collective action clauses, it can approach the trustee representing the bondholders with a renegotiation offer, who in turn can put the proposal to a vote of all bondholders. Currently CACs are mainly found in sovereign bonds issued in London under English law ${ }^{19}$. Supporters of a contractual approach to sovereign debt restructuring favor extending such clauses to all sovereign bond issues.

This approach has been endorsed by academics and in some official reports (Eichengreen, 1999; Kenen, 2001; G-10, 1996; G-22, 1998). As is often the case in policy debates, there are significant policy differences on how intrusive public policy should be in promoting the use of CACs even among the proponents of the contractual approach. Thus, while current G-7 policy is to prod and nudge issuers to adopt CACs the official community insists on a purely voluntary adoption of CACs. In contrast, several academic commentators have urged that the adoption of CACs be subsidized, and possibly even mandated (Eichengreen,

\footnotetext{
${ }^{19}$ See Eichengreen (2003) for a discussion of collective action clauses. Most sovereign bonds are governed by either English or New York law. While English law allows for a supermajority of bondholders to amend the bond's financial terms, under New York law it was assumed that unanimous consent of all bondholders was required to change the bond's payment terms. The trust indenture act of 1939 does indeed require unanimous consent for the restructuring of corporate bonds issued in the US. Although this requirement does not apply to sovereign bonds issued in the US, a unanimity rule has always been the norm for sovereign bonds issued in New York.
} 
1999; Kenen, 2001) $)^{20}$.

Returning to our model, if we interpret r-debt and n-debt as bonds respectively with and without collective action clauses, it is clear that the voluntary, market-led approach will not succeed in making debt structures more efficient ex ante. Propositions 6 and 7 reveal that sovereigns would issue an excessive amount of bonds without collective action clauses even if they are fully aware of their ex-post benefits. This is our Gresham Law for sovereign debt: bad debt crowds out good debt in equilibrium.

However, the ex-post inefficiency of equilibrium sovereign debt structures does not mean that a more intrusive approach based on taxes and subsidies will be ex-ante efficient in our model. Suppose that n-debt is taxed at rate $\tau$ and r-debt is subsidized at rate $\sigma$, so that a country that issues a quantity $D_{02}^{n}$ of n-debt must pay a tax $\tau D_{02}^{n}$ and receives a subsidy $\sigma D_{02}^{r}$ on r-debt. Suppose furthermore that the tax and the subsidy balance each other at the country level $\left(\tau D_{02}^{n}=\sigma D_{02}^{r}\right)$, implying that the system involves no cross-country transfer, and its welfare impact comes purely from the effect of the tax and the subsidy on equilibrium debt structures. We then obtain the following result.

Proposition 8 Taxing $n$-debt and subsidizing $r$-debt induces a substitution of the former by the latter, but reduces the borrowing country's welfare.

Proof. See appendix.

As one might expect based on our previous analysis, when the tax rate $\tau$ increases, sovereigns substitute r-debt for n-debt, but this only aggravates the dilution problem and leads to more frequent defaults. In the limit where $\tau=1$ (r-debt is basically mandatory) the economy is in the same situation as in the

\footnotetext{
${ }^{20}$ Eichengreen (1999) and Kenen (2001) argue that the IMF should provide an incentive for countries to adopt the clause by indicating that it is prepared to lend more generously to sovereigns that have included a collective action provision in their debts.
} 
dilutable r-debt case analyzed in section 6 . The country's welfare is lower than when dilution can be mitigated by n-debt (which is precisely why a sovereign is issuing some n-debt in equilibrium).

Absent externalities, asymmetric information, or political agency problems, that would distort the sovereign's choice of debt structure ex-ante, there can be no ex-ante benefit in influencing the sovereign's choice through a tax and subsidy scheme. Such a policy would not only raise the cost of borrowing, as has been commonly argued, but also result in excessive borrowing and default costs because of debt dilution ${ }^{21}$.

\subsection{The statutory approach}

Those who favor a more interventionist policy, modeled on existing practice in corporate bankruptcy, believe that the introduction of CACs in sovereign bond issues can only facilitate debt restructuring in a very limited way. They believe that the contractual approach will neither do much to reduce uncertainty surrounding the resolution of debt crises nor significantly limit gaming behavior by vulture funds and the like. The notion of a bankruptcy regime for sovereigns has for the first time been seriously considered by the international community in 2002, following the proposal by Anne Krueger (2002), the I.M.F.'s deputy managing director, for the establishment of a Sovereign Debt Restructuring Mechanism (SDRM) ${ }^{22}$. Following over a year of intensive debate and consultation, this project failed to gain the full support of the international community, partly due to criticisms by the investor community and some scholars that its implementation would unduly weaken creditor rights and undermine the sovereign debt market (Institute of International Finance, 2002 ; Shleifer,

\footnotetext{
${ }^{21}$ To be fair to the advocates of intervention to facilitate debt restructuring, there are likely to be political agency problems in reality, and the availability of I.M.F. programs per se induces even further distortions towards hard sovereign debt.

22 The notion of a "bankruptcy court for sovereigns" has a long history that goes back to Adam Smith. It has been popularized in the 1990s by Sachs (1995). See Rogoff and Zettelmeyer (2002) for a review of the recent developments on this proposal.
} 
2003).

Our analysis underscores some of these concerns. If the bankruptcy regime only facilitates sovereign debt restructuring by coordinating creditors $^{23}$ this would be equivalent in our model to forcing debt to be more renegotiationfriendly and would be welfare-reducing.

However, a sovereign bankruptcy institution could also enforce debt seniority and priority, as is the case for corporate bankruptcy. Such an institution would then address the underlying inefficiency in sovereign debt more effectively than the contractual approach. By replacing de facto seniority prevailing under laissez-faire with a de jure seniority a sovereign bankruptcy mechanism could result in substantial efficiency improvements. In our model a time-based priority rule where early lenders (who have lent in period 0) are senior to later lenders (who are lending in period 1) would lead to a Pareto improvement.

For concreteness, consider the sovereign debt restructuring procedure where all creditors are required to delegate renegotiation authority to a creditor committee, who has the exclusive right to make a restructuring proposal $\hat{\eta}$ (that is, a representative of creditors makes a take-or-leave offer to the sovereign $)^{24}$. The sovereign can only accept or reject the offer. If the sovereign rejects the offer the restructuring game ends, with the sovereign getting $y_{2}(1-\gamma)$ and creditors getting no debt repayment ${ }^{25}$. If the sovereign accepts the offer his payoff is

\footnotetext{
${ }^{23}$ This is how the case for the statutory approach has generally been made by its proponents (see, e.g., Krueger, 2002). Haldane et al (2003) argue that the main advantage of the statutory approach relative to the contractual one is that it facilitates the negotiation in a context of asymmetric information.

${ }^{24}$ Note that creditor exclusivity in the initiation of a restructuring offer is not what the SDRM (2003) plan proposed by the IMF envisages. On the contrary, the IMF plan only allows for debtor initiation and even gives the debtor discretion on which debts to include and which to exclude. Not surprisingly the IMF plan on this dimension further fuelled concerns on weakening creditor protections and excessively strengthening sovereign debtor's hands.

${ }^{25}$ An alternative end-game could be to let the sovereign revert back to uncoordinated renegotiations with creditors. The sovereign's payoff in that case would be unchanged but creditors' payoffs could be higher, with n-creditors again benefiting from their higher de facto seniority. It would seem that under this alternative end-game incentives towards the introduction of de facto seniority may still be present. But this is not the case under the procedure we described, where a creditor committee makes a take-it-or-leave it offer $\hat{\eta}$. This would only be true if n-
} 
$(1-\rho) y_{2}-\hat{\eta}$ and creditors get $\hat{\eta}$. Creditors would then collectively conceed a "haircut" of $\frac{D_{2}-\hat{\eta}}{D_{2}}$. The repayment $\hat{\eta}$ the sovereign agrees to make is then distributed among creditors according to absolute priority, with priority based on a first-in-time issuance rule. That is, for a given debt $D_{2}=\left(D_{02}+D_{12}\right)$, the holders of the debt claim $D_{12}$ would not recover anything out of the agreed repayment $\hat{\eta}$ until the holders of the debt $D_{02}$ are paid in full.

Note that the enforcement of this rule would entirely eliminate the sovereign's incentives to dilute outstanding debt $D_{02}$ at time $t=1$. Therefore, a sovereign bankruptcy procedure along the lines outlined above would eliminate the need for initial creditors to make their debt claim difficult to restructure. They would then optimally choose to issue only r-debt at $t=0$, so that a Pareto improvement would result at $t=0$. We emphasize this conclusion in the proposition below:

Proposition 9 Under a perfectly enforceable de jure priority rule for sovereign debt a country can achieve an optimal debt structure which puts its welfare at the (commitment) first-best.

Proof. See discussion above.

The above highly simplified procedure is, of course, an idealization that works in the context of our simple model. Real world sovereign debt restructurings are much more complex and the difficult policy question to be resolved is how priority can be legally enforced for sovereign debt. One way along the lines of the simple procedure above proposed in Bolton and Skeel (2004) is to have the court enforce a first-in-time rule through a cram-down rule adapted to fit the sovereign debt context. Another possible way, proposed by Zettelmeyer

creditors also had a veto right in the sovereign debt restructuring procedure and could insist on getting their outside option payoff. Interestingly, even if the procedure were to grant such a veto right it would still bring about an ex-post and ex-ante efficiency improvement, as it would be able to overcome the non-renegotiation constraint of n-debt. 
(2003) is to have courts enforce subordination clauses in sovereign debt issues. The idea is to give senior claim-holders the right to recover payment from junior claimholders, who have been able to extract a restructuring agreement which violates the priority ordering. One potential advantage of Zettelmeyer's proposal is that it could in principle be implemented independently of the establishment of a statutory regime. A possible drawback, however, is that it imposes a potentially onerous monitoring requirement on creditors, who need to be aware of subordination clauses in pre-existing debt. In addition, the statutory solution allows more flexibility in the application of the seniority rule - a flexibility that might be desirable for reasons explained in the following section.

\subsection{Optimal dilution}

One concern one might have with the strict enforcement of a time-based priority rule is that it may give rise to a debt overhang problem and put the sovereign in a position ex post where it cannot borrow to finance valuable investment because it has already accumulated too much debt. As a way of reducing this risk it may be desirable even from an ex ante perspective to allow for some debt dilution ${ }^{26}$. Alternatively, it may be desirable to allow for deviations from an absolute priority rule under the sovereign bankruptcy regime, as is the case in corporate bankruptcy.

We explore this idea in this section by introducing a plausible new feature into the model. We shall allow the sovereign to take an action in period 1 that can reduce the negative impact of a default on the domestic economy. This action increases domestic output by $(\alpha+\beta) y_{2}$ in period 2 , but requires an expenditure of $\alpha y_{2}$ in period 1. For simplicity, we assume that this increase in domestic output cannot be pledged in repayment to foreign creditors. We further assume that the country is not able to finance the new expenditure with

\footnotetext{
${ }^{26}$ Diamond (1993) presents a model in which dilution might play a useful role as a buffer against negative shocks.
} 
period 1 output, so that it has to borrow $\alpha y_{2}$ in period 1.

If the bankruptcy court gives absolute priority to the period 0 lenders, then the sovereign cannot raise any new funds in period 1 . For the country to be able to finance the welfare-enhancing expenditure in period 1, the bankruptcy regime would have to violate the seniority of early lenders.

Suppose that the bankruptcy court grants protection to a sovereign only if it is insolvent (when $\gamma y_{2}<D_{02}^{r}$ ) and suppose that the bankruptcy court grants higher priority to new lenders to cover the expenditure $\alpha y_{2}$.

Under these assumptions the country's budget constraint and ex ante welfare are given by respectively

$$
g=(\lambda-\alpha) \int_{0}^{D_{02}^{r} / \gamma} y f_{2}(y) d y+D_{02}^{r} \int_{D_{02}^{r} / \gamma}^{+\infty} f_{2}(y) d y,
$$

and

$$
U_{0}=V(g)-g+E_{0}\left(y_{1}+y_{2}\right)+(\beta-\rho) \int_{0}^{D_{02}^{r} / \gamma} y f_{2}(y) d y .
$$

The expected cost of dilution arising from the new priority lending in period 1 is captured in the term in $\alpha$ in the first equation. Because of this cost the sovereign must promise a larger $D_{02}^{r}$ to finance the same $g$, and therefore faces a higher probability of default (for the same level of borrowing $g$ ). The second equation captures the welfare benefit of dilution (the term in $\beta$ ). If $\beta$ is larger than $\rho$-that is, if the period 1 expenditure more than offsets the deadweight cost of default - conditional dilution unambiguously increases the country's welfare. If $\beta$ is smaller than $\rho$, the welfare impact of conditional dilution is ambiguous, but remains positive if $\alpha$ is sufficiently small relative to $\beta$.

Proposition 10 It may be optimal for the bankruptcy court to grant seniority to post-default lenders over pre-default lenders.

Proof. See discussion above. 
The right of dilution given to the court can be interpreted as the analog of debtor-in-possession lending in corporate bankruptcy regimes. Note that the original creditors suffer from the dilution so they would never vote for it, if given the opportunity. The optimal conditional dilution policy cannot, therefore, be implemented simply by coordinating creditors ex post. The court must be granted the discretionary power of deviating from the absolute priority rule.

\section{Concluding Comments}

This paper presents a model of sovereign debt crises which, although stylized, is versatile enough to lend itself to the analysis of a number of questions that have been discussed in the recent debates on the international financial architecture. The endogeneity of the debt structure implies that the normative analysis has to go beyond statements that debt workouts should be made more orderly and sovereign creditors coordinated in a crisis. These statements are correct in an ex post sense, but from an ex ante perspective dangerous liability structures arise for a reason.

At the same time, our analysis does not support a Panglossian view that sovereign debt contracts are efficient ex ante and that there is no scope for welfare-improving reforms. We do find that sovereign debt might be excessively difficult to restructure under laissez-faire (even from an ex ante point of view), and that public intervention is warranted. Our model points to a sovereign debt restructuring mechanism that shares many features with corporate bankruptcy regimes. In particular, it should not only solve the classical common pool problem between creditors but also establish a seniority structure between the pre-default lenders, and enjoy some discretion in granting super-seniority to post-default lenders.

This model abstracted from a number of issues that may be quite relevant in 
the real world. One such issue is debt maturity. Short-term debt is another way of forestalling dilution: it allows creditors to price any dilution in the interest rate at which they roll over their claims, or punish the sovereign by a debt rollover crisis when dilution becomes too large. However, short-term debt could make sovereigns excessively vulnerable to debt rollover crises (Jeanne, 2004). Our model suggests that if the maturity of sovereign debt were excessively short because of the nonexclusivity problem, then this inefficiency could be taken care of by a statutory bankruptcy mechanism making long-term debt senior to shortterm debt. The normative implications, thus, would be close to those we have obtained here (a conjecture that we plan to explore further in future work).

The analysis could be extended to take other agency problems than those between debtors and creditors into consideration, in particular political agency problems between citizens and their governments. In this paper it was unambiguously optimal to relax the credit constraints in the international debt market because governments were assumed to be benevolent. The welfare analysis would be very different if decisions were taken by self-interested policymakers who do not maximize domestic welfare. Rationing policymakers, then, could increase the welfare of their citizens. 


\section{APPENDIX}

\section{Proof of Proposition 2}

We assume that condition (3) is satisfied (the proof is easy to extend to the case where it is not). Then creditors as a whole receive $D_{2}=D_{2}^{r}+D_{2}^{n}$ under full repayment (case (i) of Proposition 1), $\lambda y_{2}$ under partial repayment (case (ii)), and zero repayment if there is a full default (case (iii)). The lenders' binding participation constraint implies that the expected debt repayment is equal to $g$

$$
g=\int_{D_{2}^{n} / \lambda}^{D_{2} / \gamma} \lambda y_{2} f_{2}\left(y_{2}\right) d y_{2}+\int_{D_{2} / \gamma}^{+\infty} D_{2} f_{2}\left(y_{2}\right) d y_{2}
$$

The deadweight cost of default is equal to $\rho y_{2}$ if default is partial, to which one must add $\lambda y_{2}$ under full default. Thus the expected deadweight loss of default is

$$
E_{0}(\ell)=\int_{0}^{D_{2} / \gamma} \rho y_{2} f_{2}\left(y_{2}\right) d y_{2}+\int_{0}^{D_{2}^{n} / \lambda} \lambda y_{2} f_{2}\left(y_{2}\right) d y_{2}
$$

If $D_{2}^{n}>\lambda \underline{y}$, reducing $D_{2}^{n}$ below $\lambda \underline{y}$ and increasing $D_{2}^{r}$ so as to keep their sum $D_{2}$ constant is optimal since it has the effect of increasing $g$ and reducing $E_{0}(\ell)$. Thus the optimal debt structure has $D_{2}^{n}<\lambda \underline{y}$ (the inequality does not need to be strict if $f_{2}(\cdot)$ does not have a probability mass in $\underline{y}$ ).

The sovereign chooses $g$ to maximize

$$
U_{0}=V(g)-g+E_{0}\left(y_{1}+y_{2}\right)-\rho \int_{0}^{D_{2}(g) / \gamma} y_{2} f_{2}\left(y_{2}\right) d y_{2},
$$

where $D_{2}(g)$ is the solution to (13) in which $D_{2}^{n}$ has been set to zero ${ }^{27}$

$$
g=\int_{0}^{D_{2}(g) / \gamma} \lambda y_{2} f_{2}\left(y_{2}\right) d y_{2}+\int_{D_{2}(g) / \gamma}^{+\infty} D_{2}(g) f_{2}\left(y_{2}\right) d y_{2} .
$$

If $g^{*}<\gamma \underline{y}$, the sovereign can finance the first-best level of expenditure with a default-free debt structure by issuing $D_{2}=g^{*}$. By contrast, if $g^{*}>\gamma \underline{y}$, then

\footnotetext{
${ }^{27}$ Such equations can have multiple solutions, in which case the economically relevant solution is the lowest one.
} 
the sovereign must incur a strictly positive probability of default to finance $g^{*}$. The sovereign underborrows, as

$$
\frac{d\left[\int_{0}^{D_{2}(g) / \gamma} y_{2} f_{2}\left(y_{2}\right) d y_{2}\right]}{d g}>0 .
$$

\section{Proof of Proposition 6}

Assume that $D_{02}^{n} \leq \lambda \underline{y}$, so that the probability of a full default is equal to zero. We know that because of (11), the sovereign issues some r-debt that is diluted in equilibrium and that $g<g^{*}$. If $D_{02}^{n}$ is strictly below $\lambda \underline{y}$, then a small (first-order) increase in n-debt $\delta$ would be repaid with probability 1 , and $g$ could be increased by $\delta$ at no cost. $D_{02}^{n}$, therefore, must be at least equal to $\lambda \underline{y}$. Assume that $D_{02}^{n}$ is equal to $\lambda \underline{y}$, and again let us increase it by first-order amount $\delta$. Then the probability of a full default increases from zero to

$$
f_{2}(\underline{y}) \frac{\delta}{\lambda}
$$

which is the probability that $y_{2}$ falls between $D_{02}^{n} / \lambda$ and $\left(D_{02}^{n}+\delta\right) / \lambda$.

The small increase in $D_{02}^{n}$ has two effects. First, since $\delta$ is almost always fully repaid (to a first-order approximation), it allows the government to increase $g$ by $\delta$. The resulting increase in welfare is,

$$
\left(V^{\prime}(g)-1\right) \delta
$$

which is strictly positive if $g$ is strictly below the first-best level.

Second, the deadweight loss increases by the amount of the sanction if there is a full default. To a first-order approximation, the expected deadweight loss increases by,

$$
f_{2}(\underline{y}) \frac{\delta}{\lambda} \cdot \lambda \underline{y}
$$


i.e., the probability of a full default times the amount of the sanction when output is equal to $\underline{y}$. Thus, it is optimal to issue some n-debt up to a level where there is a strictly positive probability of full default if and only if,

$$
\left(V^{\prime}(g)-1\right) \delta>f_{2}(\underline{y}) \frac{\delta}{\lambda} \cdot \lambda \underline{y}
$$

or,

$$
V^{\prime}(g)-1>f_{2}(\underline{y}) \underline{y} .
$$

This condition is necessarily satisfied if $f_{2}(\underline{y}) \underline{y}=0$.

\section{Proof of Proposition 7}

First, let us show that condition (12) is necessary. Assume that it is not satisfied, i.e.

$$
0<\frac{D_{02}^{n}}{\lambda}<\frac{D_{02}^{r}}{\rho} .
$$

The period 0 expenditure and expected deadweightloss are respectively given by,

$$
g=D_{02}^{n} \int_{D_{02}^{n} / \lambda}^{+\infty} f_{2}(y) d y+D_{02}^{r} \int_{D_{02}^{r} / \rho}^{+\infty} f_{2}(y) d y
$$

and

$$
E_{0}(\ell)=\rho \int_{0}^{D_{02}^{r} / \rho} y f_{2}(y) d y+\lambda \int_{0}^{D_{02}^{n} / \lambda} y f_{2}(y) d y .
$$

Equation (17) uses the facts that $D_{02}^{n}$ is repaid if it is smaller than $\lambda y_{2}$ (Proposition 1) and that $D_{02}^{r}$ is repaid if it is smaller than $\rho y_{2}$, and is otherwise completely diluted (Proposition 3). Equation (18) uses that the deadweight loss amounts to $\rho y_{2}$ if $y_{2}<D_{02}^{r} / \rho$, to which one must add $\lambda y_{2}$ if $y_{2}<D_{02}^{n} / \lambda$.

Let us increase $D_{02}^{n}$ by a small amount $d D_{02}^{n}$ and decrease $D_{02}^{r}$ by a small amount $d D_{02}^{r}$ so as to keep the expected deadweight loss constant. We denote by,

$$
\delta=\frac{D_{02}^{n}}{\lambda} f_{2}\left(\frac{D_{02}^{n}}{\lambda}\right) d D_{02}^{n}
$$


the increase in $E_{0}(\ell)$ caused by the additional n-debt. Then differentiating (17) gives,

$$
d g=\left(h\left(\frac{D_{02}^{n}}{\lambda}\right)-h\left(\frac{D_{02}^{r}}{\rho}\right)\right) \delta,
$$

where $h(x) \equiv \int_{x}^{+\infty} f_{2}(y) d y /\left(x f_{2}(x)\right)$. Assumption A1 implies that $d g>0$, so it is possible to increase $g$ without increasing the expected deadweight loss. So a debt structure with $0<D_{02}^{n} / \lambda<D_{02}^{r} / \rho$ cannot be optimal. This proves that condition (12) is necessary.

Suppose now that (12) is satisfied. Then repayment occurs if and only if $D_{02}^{n}+D_{02}^{r}$ is smaller than $\gamma y_{2}$. If $D_{02}^{n}+D_{02}^{r}$ is strictly larger than $\gamma y_{2}$, there is a default in which the deadweight loss is equal to $\gamma y_{2}$. Thus one has

$$
\begin{aligned}
g & =\left(D_{02}^{n}+D_{02}^{r}\right) \int_{\left(D_{02}^{n}+D_{02}^{r}\right) / \gamma}^{+\infty} f_{2}(y) d y \\
E_{0}(\ell) & =\gamma \int_{0}^{\left(D_{02}^{n}+D_{02}^{r}\right) / \gamma} y f_{2}(y) d y .
\end{aligned}
$$

Both $g$ and $E_{0}(\ell)$ depend on the sum $D_{2} \equiv D_{02}^{n}+D_{02}^{r}$. This sum is uniquely determined in equilibrium, not the components $D_{02}^{n}$ and $D_{02}^{r}$, which can be chosen arbitrarily subject to the zero-profit condition for lenders. One particular solution is $D_{02}^{n}=D_{2}, D_{02}^{r}=0$, i.e., pure n-debt. This proves the proposition.

\section{A counterexample}

We now highlight that if the distribution of $y_{2}$ does not satisfy assumption A1, it may be optimal for the government to issue some r-debt in equilibrium. We consider the situation where $y_{1}=0$ and $y_{2}$ has the binomial distribution:

$$
\left\{\begin{array}{c}
y_{2}=y_{L} \text { with probability } p_{L} \\
y_{2}=y_{H} \text { with probability } p_{H}
\end{array}\right.
$$

In this example the sovereign is obviously indifferent between any combination of r-debt and n-debt as long as the debt remains default-free. That is, for 
any amount $g$ raised that is less than or equal to $\rho y_{L}$ the optimal debt structure is indeterminate. For

$$
\rho y_{L}<g \leq \gamma y_{L}
$$

the sovereign strictly prefers n-debt over r-debt, as n-debt is safe and has face value $D^{n}=g$, while r-debt is either risky or not sustainable. Indeed, for $g>\rho y_{L}$ r-debt leads to a default and full dilution in state $y_{L}$. The face value of the risky r-debt is then given by $D^{r}(g)=\frac{g}{p_{H}}$ when it is sustainable (r-debt is sustainable if and only if $\left.\frac{g}{p_{H}} \leq \rho y_{H}\right)$.

However, for $\gamma y_{L}<g \leq \rho p_{H} y_{H}$ r-debt is preferred to n-debt since both forms of debt are now risky and both lead to default in state $y_{L}$, but n-debt involves the higher expected deadweight cost of default of $p_{L} \gamma y_{L}$. In this situation the cost of borrowing $g$ under respectively r-debt and n-debt (in terms of expected foregone future consumption) is given by $C^{r}(g)=p_{L} \rho y_{L}+g$ and $C^{n}(g)=p_{L} \gamma y_{L}+g$. As can be easily verified, the sovereign is indifferent between borrowing all its debt in the form or r-debt here, or borrowing any amount up to $\lambda y_{L}$ in safe n-debt and the remainder $g-\lambda y_{L}$ in r-debt. However, if $g$ is raised entirely with r-debt, this debt is sustainable as only if $\frac{g}{p_{H}} \leq \rho y_{H}$. On the other hand, if only $\left(g-\lambda y_{L}\right)$ is raised with $\mathrm{r}$-debt then the total debt is sustainable if

$$
\lambda y_{L}+\frac{g-\lambda y_{L}}{p_{H}} \leq \gamma y_{H}
$$

or,

$$
p_{H} \lambda y_{L}+g-\lambda y_{L} \leq \gamma p_{H} y_{H} .
$$

Notice that since the RHS of this inequality is higher and the LHS lower than in the inequality $g \leq \rho p_{H} y_{H}$, issuing a mix of n-debt and r-debt allows the sovereign to issue more debt. More precisely, when $\gamma y_{L} \leq \rho p_{H} y_{H}<g$ and $g \leq p_{H} \gamma y_{H}+\left(1-p_{H}\right) \lambda y_{L}$ then it is strictly optimal for the sovereign to borrow with a mixture of r-debt and n-debt. 
Finally, for $p_{H} \gamma y_{H}+\left(1-p_{H}\right) \lambda y_{L}<g \leq \gamma y_{H}$ only n-debt is sustainable and is therefore preferred (any borrowing requirement $g>\gamma y_{H}$ cannot be funded with either form of debt in this example).

In short, this example illustrates how for low borrowing requirements n-debt may weakly dominate $\mathrm{r}$-debt, for intermediate $g$ the ranking between the two forms of debt is reversed, while for high borrowing requirements it is again $\mathrm{n}$-debt that is preferable.

\section{Proof of Proposition 8}

Equation (17) is replaced by,

$$
g=D_{02}^{n}\left(\int_{D_{02}^{n} / \lambda}^{+\infty} f_{2}(y) d y-\tau\right)+D_{02}^{r}\left(\int_{D_{02}^{r} / \rho}^{+\infty} f_{2}(y) d y+\sigma\right),
$$

and the expected deadweight loss is still given by equation (18).

Going through the same steps as in the proof of Proposition 7, one can show that (19) is replaced by,

$$
d g=m\left(\frac{D_{02}^{n}}{\lambda}, \frac{D_{02}^{r}}{\rho}, \tau\right) \delta,
$$

with $m(\cdot, \cdot, \cdot)$ defined by,

$$
m(\bar{x}, \stackrel{+}{y}, \bar{\tau}) \equiv h(x)\left(1-\frac{\tau}{1-F_{2}(x)}\right)-h(y)\left(1+\frac{\lambda}{\rho} \frac{\tau x}{y\left(1-F_{2}(y)\right)}\right)
$$

$F_{2}(\cdot)$ denotes the cdf of $y_{2}$, and $\sigma$ was substituted out using $\tau D_{02}^{n}=\sigma D_{02}^{r}$.

One can check that $m$ is decreasing with $D_{02}^{n}$ and increasing with $D_{02}^{r}$ (the latter because $D_{02}^{r}\left(1-F_{2}\left(D_{02}^{r} / \rho\right)\right)$ is increasing with $D_{02}^{r}$ in an efficient debt structure). We know from Proposition 7 that $m$ is strictly positive if $\tau=0$ and there is dilution $\left(D_{02}^{n} / \lambda<D_{02}^{r} / \rho\right)$. Increasing $\tau$ reduces $m$, which becomes negative for large enough values of $\tau$. It follows that for large enough $\tau$ the optimal debt structure (with $m=0$ ) is associated with some dilution in equilibrium. 
The comparative static impact of $\tau$ on the equilibrium debt structure can be derived graphically as follows. The equilibrium relationship $m=0$ defines an upward sloping locus in the space $\left(D_{02}^{r}, D_{02}^{n}\right)$ (see Figure 5). The equilibrium is at the intersection between this curve and the locus (20), which is downward sloping. An increase in the tax rate on n-debt, $\tau$, shifts the locus $m=0$ downward, and so reduces the amount of n-debt and increases that of r-debt.

In equilibrium, the sovereign's budget constraint is still given by (17) since the tax and the subsidy cancel each other. The tax increases the agency cost of debt $E_{0}(\ell)$ for any given level of $g$, or equivalently reduces the level of $g$ that can be achieved by for a given agency $\operatorname{cost} E_{0}(\ell)$. It follows that the tax reduces domestic welfare in equilibrium. 


\section{References}

Barclay Michael and Clifford Smith, 1995, "The Priority Structure of Corporate Liabilities", Journal of Finance 50(3).

Bisin, Alberto and Adriano Rampini, 2004, "Exclusive Contracts and the Institution of Bankruptcy", Working paper Northwestern University

Bizer, David and Peter M. DeMarzo, "Sequential Banking," Journal of Political Economy 100(2), 41-61.

Bolton, Patrick, 2003, "Towards a Statutory Approach to Sovereign Debt Restructuring: Lessons from Corporate Bankruptcy Around the World," IMF Staff Papers 50, 41-71.

Patrick Bolton and Olivier Jeanne, 2002, "Sovereign Debt Structuring and Restructuring: An Incomplete Contracts Approach",unpublished mimeo, International Monetary Fund.

Bolton, Patrick and David Scharfstein, 1996, "Optimal Debt Structure and the Number of Creditors", Journal of Political Economy 104(1), 1-25..

Bolton, Patrick and David Skeel, 2004, "Inside the Black Box: How Should a Sovereign Bankruptcy Framework be Structured," Emory Law Journal, $53,763-822$.

Buchheit, Lee and Mitu Gulati, 2000, "Exit Consents in Sovereign Bond Exchanges", UCLA Law Review, 48.

Bulow, Jeremy, and Ken Rogoff, 1989, "A Constant Recontracting Model of Sovereign Debt", Journal of Political Economy 97, 155-78. 
Bulow, Jeremy, and Ken Rogoff, 1991, "Sovereign Debt Repurchases: No Cure for Overhang", Quarterly Journal of Economics 106(4), 1219-1235.

Chalk, Nigel A., 2002, The Potential Role for Securitizing Public Sector Revenue Flows: An Application to the Phillipines, Working Paper No. 02/106 (Washington: International Monetary Fund).

Chang, Roberto, 2002, "Electoral Uncertainty and the Volatility of International Capital Flows", mimeo, Rutgers University, http://econweb.rutgers.edu/chang

Cohen, Daniel, 1991, Private Lending to Sovereign States: a theoretical autopsy, The MIT Press.

Detragiache, Enrica, 1994, "Sensible Buybacks of Sovereign Debt", Journal of Development Economics 43, 317-333.

Dewatripont, Mathias and Eric Maskin, 1995, "Credit and Efficiency in Centralized and Decentralized Economies." Review of Economic Studies, 62, $541-55$.

Diamond, Douglas, 1993, "Seniority and Maturity of Debt Contracts", Journal of Financial Economics 33, 341-368.

Diamond, Douglas and Raghuram Rajan, 2001, "Liquidity Risk, Liquidity Creation, and Financial Fragility: A Theory of Banking", Journal of Political Economy, Vol. 109, 287-32\%.

Diamond, Douglas, 2004, "Committing to Commit: Short-term Debt When Enforcement Is Costly", Journal of Finance, VOL. LIX, NO. 4, 1447- 79. Dooley, Michael, 2000, "Can Output Losses following International Financial Crises be avoided?" NBER discussion paper No. 7531 
Eaton, Jonathan, and Mark Gersowitz, 1981, "Debt With Potential Repudiation: Theory and Estimation", Review of Economic Studies 48, 289-309.

Eichengreen, Barry, 1999, Toward a New International Financial Architecture, Institute For International Economics (Washington DC).

Eichengreen, Barry, 2003, "Restructuring Sovereign Debt", Journal of Economic Perspectives 17(4), 75-98.

Fama, Eugene F. and Merton H. Miller, 1972, The Theory of Finance (New York, Holt, Rinehart and Winston).

Gertner, Robert and David Scharfstein, 1991, "A Theory of Workouts and the Effects of Reorganization Law", Journal of Finance 46(4), 1189-1222.

Group of 10 (G-10), 1996, Resolving Sovereign Liquidity Crises (Washington DC), also known as Rey Report.

Group of 22 (G-22), 1998, Three Reports on International Financial Architecture Reform (Washington DC).

Haldane, Andrew, Penalver, Adrian, Saporta, Victoria and Hyun Song Shin, 2003, "Analytics of Sovereign Debt Restructuring", Bank of England Working Paper No. 203 (Bank of England, London, UK).

Hart, Oliver and John Moore, 1995, "Debt and Seniority: An Analysis of the Role of Hard Claims in Constraining Management," American Economic Review 85, 567-85.

Hart, Oliver and John Moore, 1998, "Default and Renegotiation: A Dynamic Model of Debt." Quarterly Journal of Economics, 113, 1-41.

Institute of International Finance, 2002, Action Plan: Strengthening Emerging Markets Finance, IIF Policy Reports (IIF, Washington DC). 
International Monetary Fund, 2003, "Assessing Public Sector Borrowing Collateralized on Future Flow Receivables", prepared by the Fiscal Affairs, International Capital Markets, Legal and Policy Development and Review Departments, June (http://www.imf.org/external/np/fad/2003/061103.htm).

Jeanne, Olivier, 2004, "Debt Maturity and the International Financial Architecture", Working Paper 04/137 (IMF, Washington DC).

Kenen, Peter, 2001, The International Financial Architecture, What's New? What's Missing?, Institute For International Economics (Washington DC).

Kletzer, Kenneth M, 1984, "Asymmetries of Information and LDC Borrowing with Sovereign Risk," Economic Journal 94, pp. 287-307.

Krueger, Anne, 2002, A New Approach To Sovereign Debt Restructuring, International Monetary Fund (Washington DC).

Lipworth, Gabrielle, and Jens Nysted, 2001, "Crisis Resolution and Private Sector Adaptation," IMF Staff Papers, Vol. 47, Special Issue, pp. 188214.

Merril Lynch, 1995, The 1995 Guide to Brady Bonds (New York: Merrill Lynch).

Obstfeld, Maurice and Ken Rogoff, 1996, Foundations of International Macroeconomics, The MIT Press (Cambridge MA).

Rogoff, Kenneth and Jeromin Zettelmeyer, 2002, "Bankruptcy Procedures for Sovereigns: A History of Ideas, 1976-2001", IMF Staff Papers 49(3), pp. 470-507.

Roubini, Nouriel, and Brad Setser, 2004, "The Reform of the Sovereign Debt Restructuring Process: Problems, Proposed Solutions, and the Argentine Episode", Journal of Restructuring Finance 1 (1), 1-12. 
Sachs, Jeffrey, 1995 "Do We Need an International Lender of Last Resort", Frank D. Graham Lecture, Princeton University.

Sachs, Jeffrey, and Daniel Cohen, 1982, "LDC Debt with Default Risk", NBER Working Paper 925.

Schwartz, Alan, 1989, "A Theory of Loan Priorities", Journal of Legal Studies 18, pp 209-261.

Schwartz, Alan, 1997, "Priority Contracts and Priority in Bankruptcy", Cornell Law Review 82, pp 1396-1435.

Shleifer, Andrei, 2003, "Will the Sovereign Debt Market Survive?", American Economic Review 93(2), AEA Papers and Proceedings, 85-90.

Smith, C.W. Jr. and J. Warner, 1979, "On Financial Contracting: An Analysis of Bond Covenants", Journal of Financial Economics 117.

Standard and Poor's, 2003, "Sovereign Defaults: Heading Lower Into 2004", 18 September 2003.

Tirole, Jean, 2002, Financial Crises, Liquidity Provision and the International Monetary System, Princeton University Press (Princeton, NJ).

White, Michelle, 1980, "Public Policy towards Bankruptcy: Me-first and other Priority Rules", Bell Journal of Economics 11, pp 550-564

Zettelmeyer, Jeromin, 2003, "The Case for an Explicit Seniority Structure in Sovereign Debt", mimeo, IMF, Washington DC. 
Figure 1. Structure of External Public Debt: Bonds versus Loans

Emerging Market Courtries: S tocks of Privately Held Debt (inbillions of US dollas)

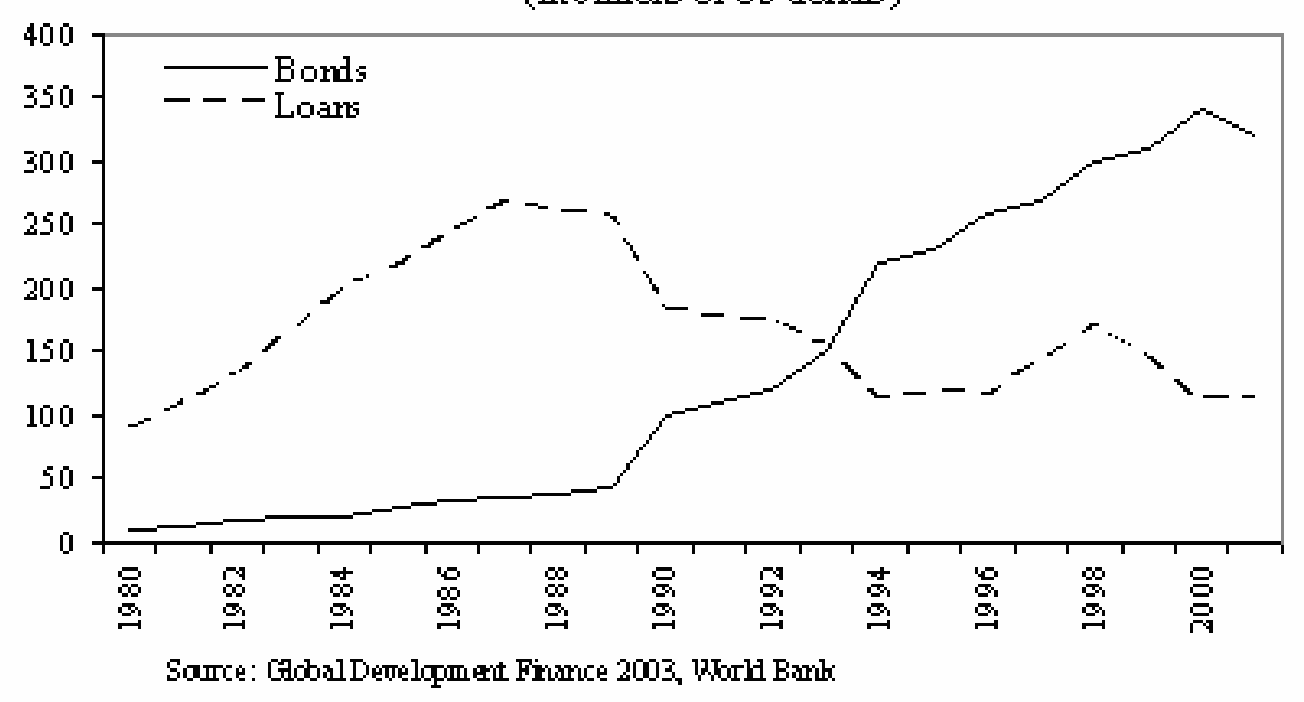


Figure 2. The repayment game in period 2

\section{$\underline{\text { Payoffs }}$}

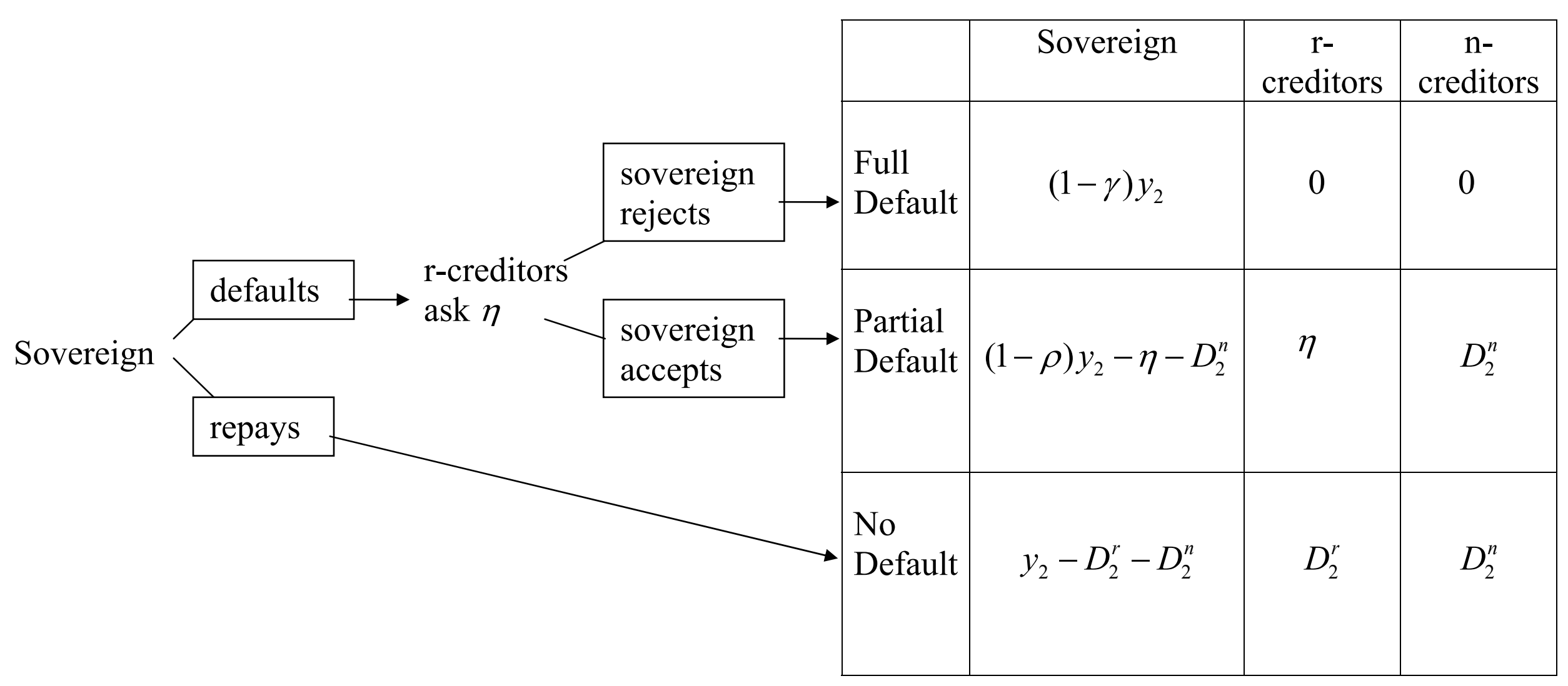



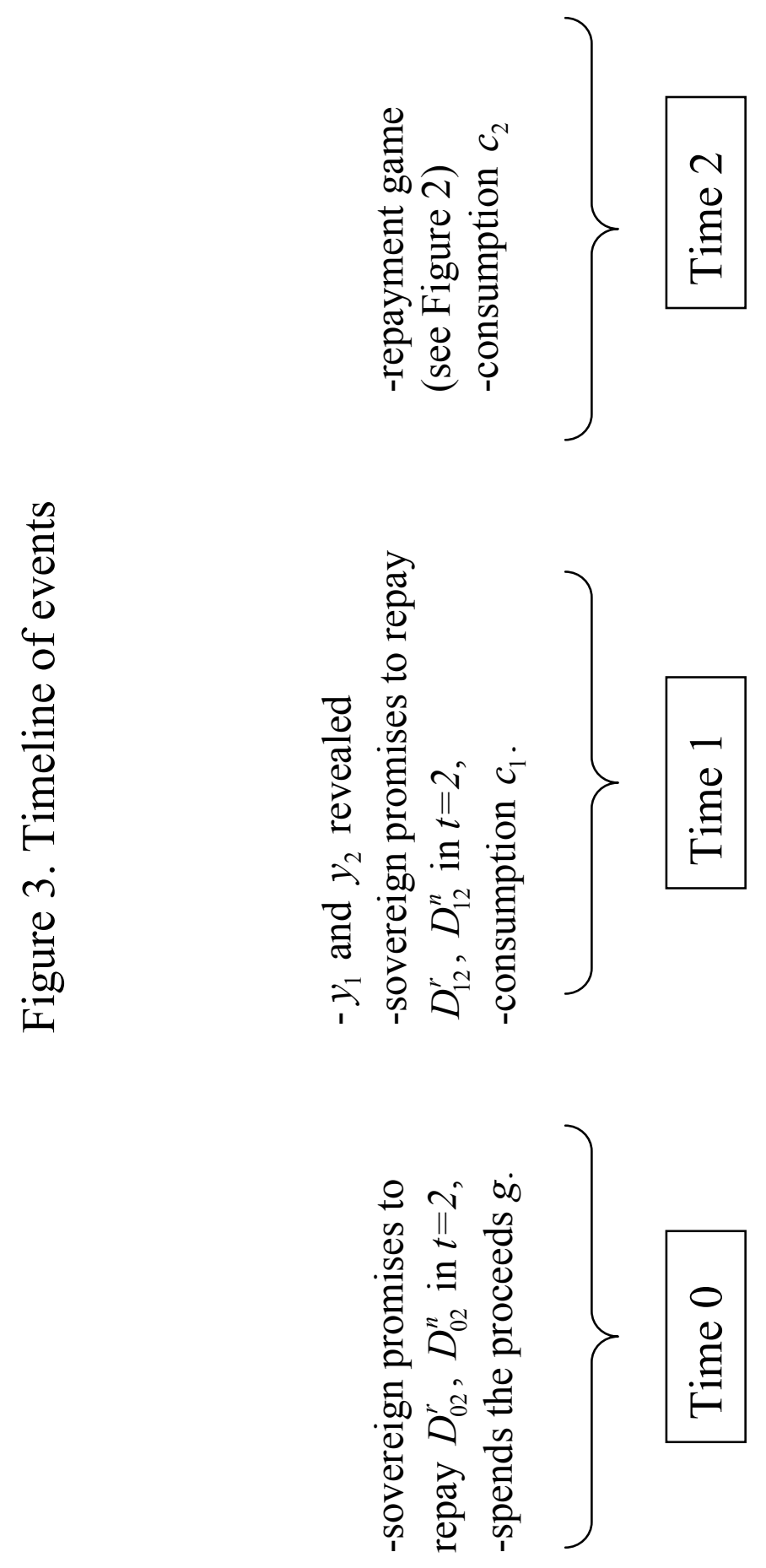


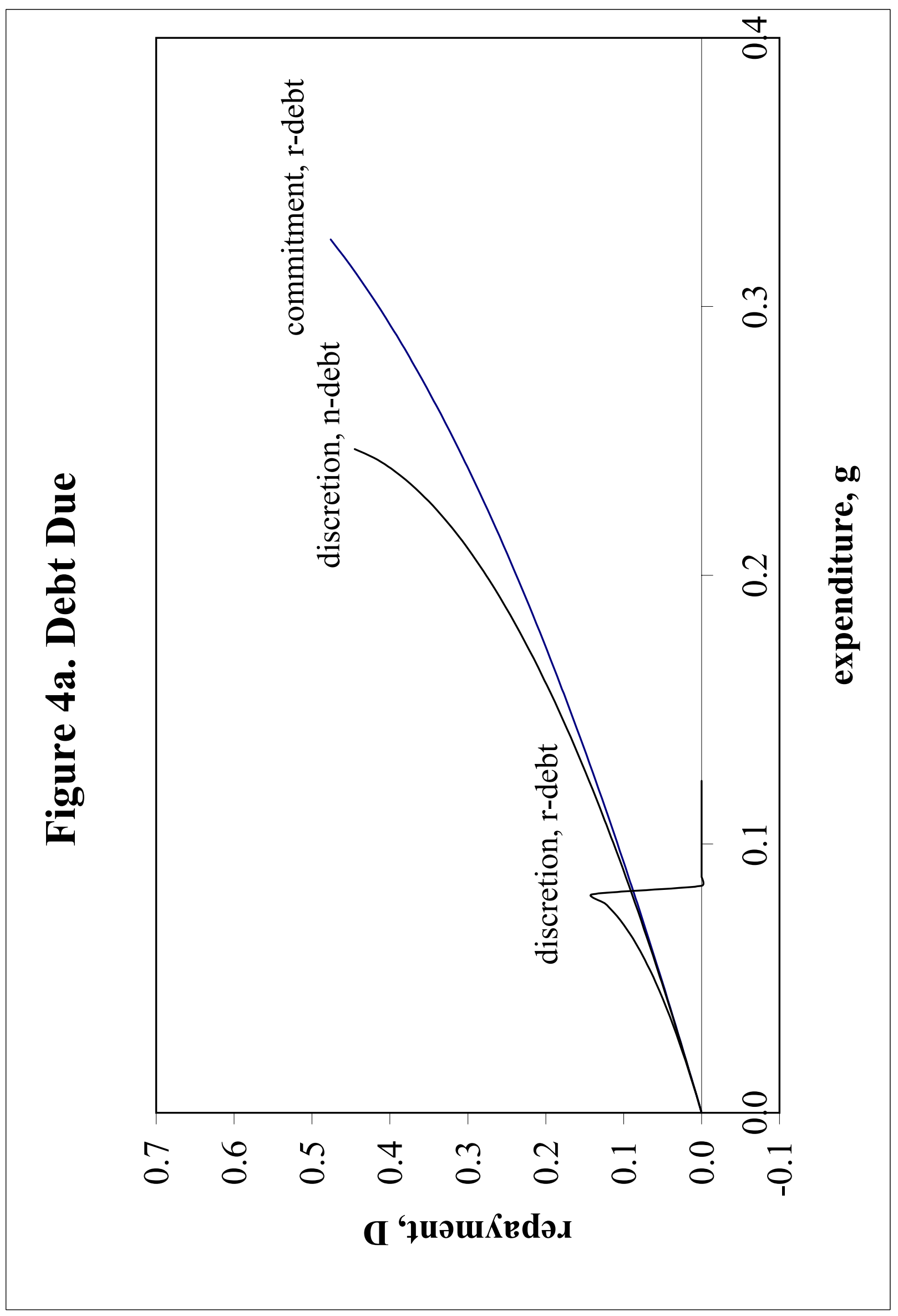




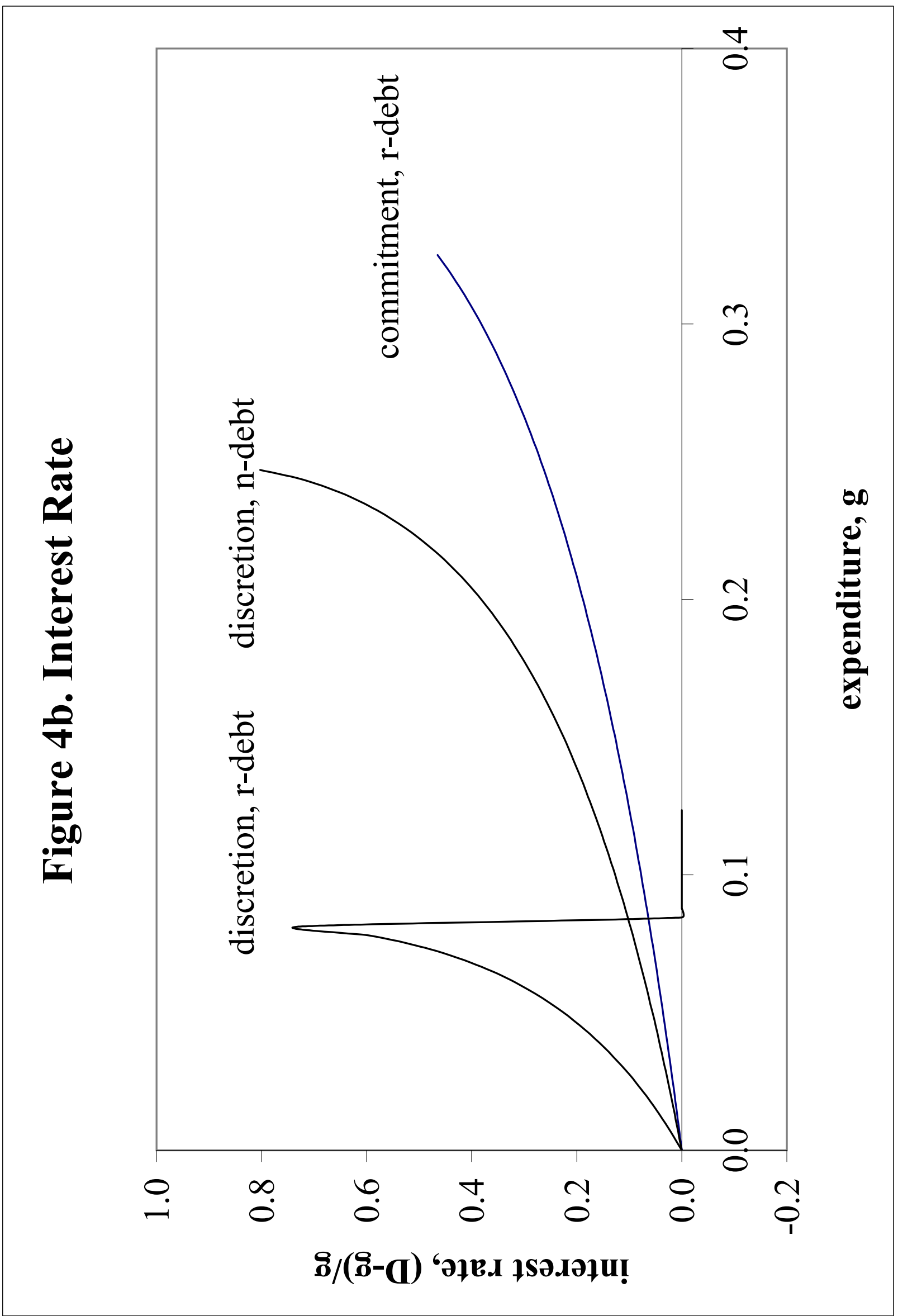




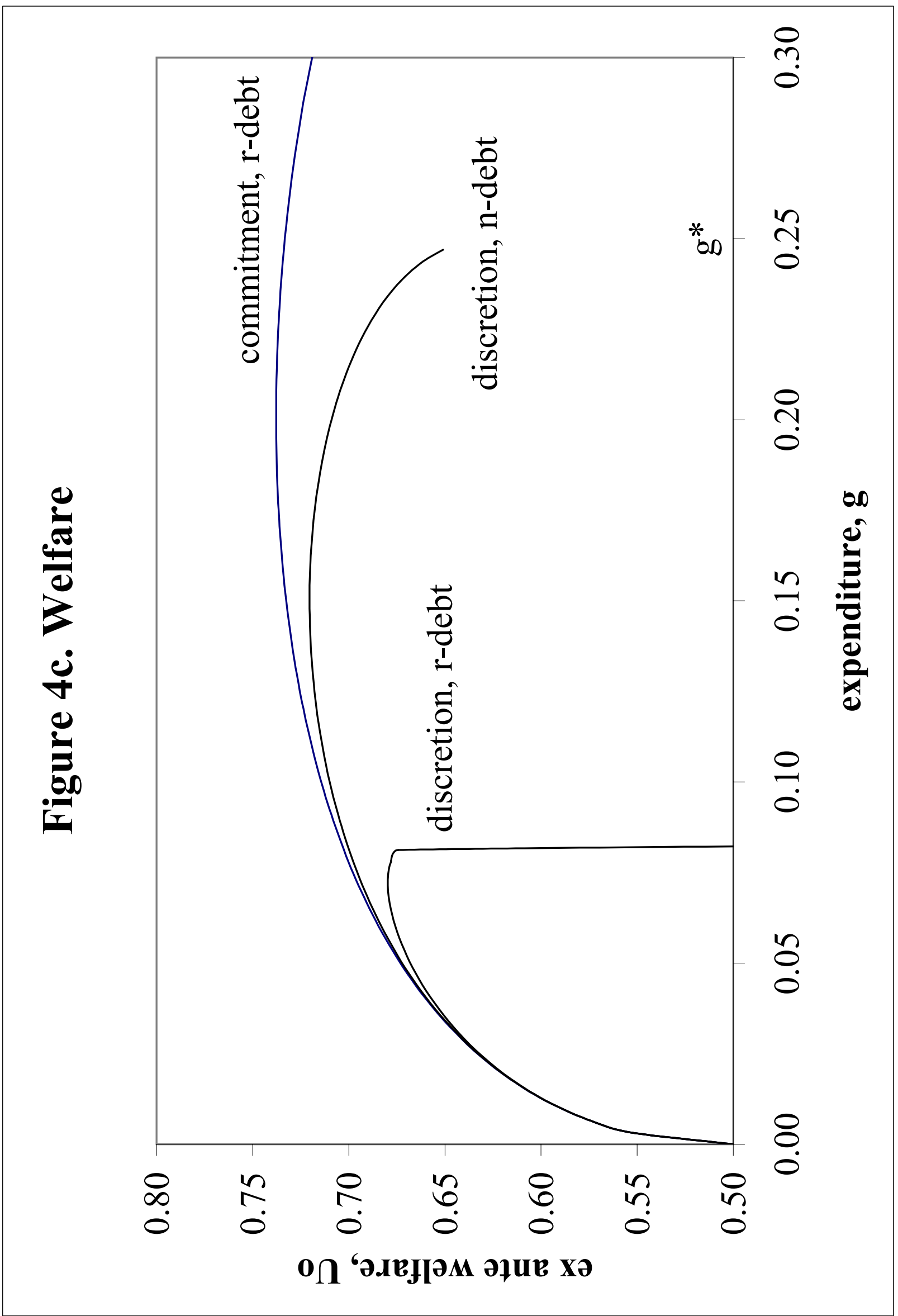


Figure 5. Proof of Proposition 8

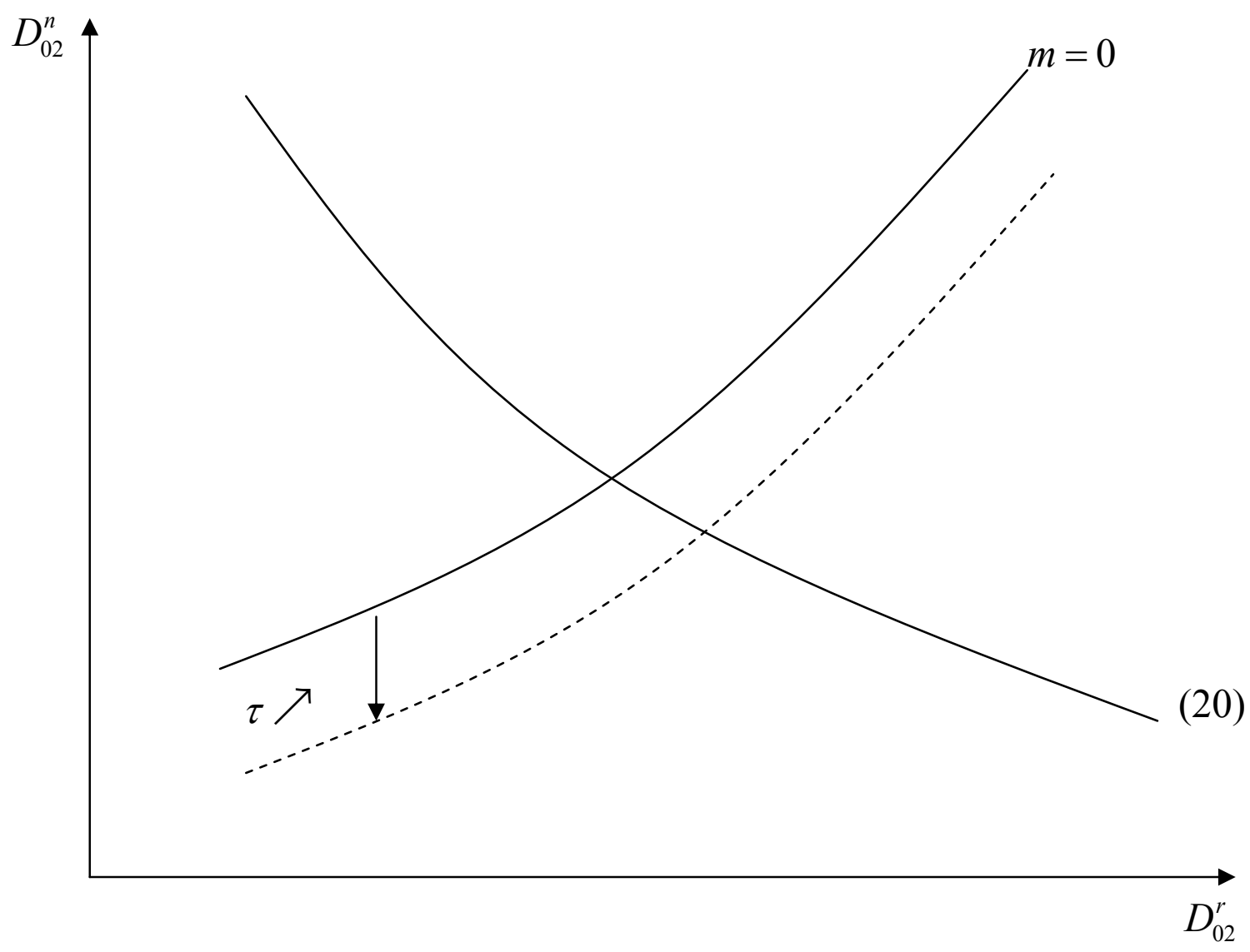

